\title{
İklim Değişikliğine Uyumda Mekânsal Planlama ve Akıllı Yönetişim Çerçevesinde Türkiye
}

\section{Spatial Planning in the Climate Change Adaptation and Turkey in the Framework of Smart Governance}

\author{
Gamze Kazancı, (D) Azime Tezer
}

İstanbul Teknik Üniversitesi Mimarlık Fakültesi, Şehir ve Bölge Planlama Anabilim Dalı, İstanbul

\section{ÖZ}

Bu makalenin amacı; kentlerde mekânsal planlamanın iklim değişikliğine uyumda etkinliğini artıracak "akıllı yönetişim" kapsamının irdelenmesi ve Türkiye'de akıllı yönetişimin mevcut durumunun tartışılmasıdır. Öncelikle iklim değişikliğinin etkileri tanımlanmış ve iki aşamalı literatür değerlendirmesi yapılmıştır. Birinci aşamada, iklim değişikliğine uyum ve mekansal planlama ilişkisinin anlaşılabilmesi için iklim değişikliğine uyumun mekânsal planlamanın hangi göstergeleri ile değerlendirilebileceği irdelenmiştir. Mekansal uyum politikaları, yönetişim modeli, uygulama düzeyi, aktörler ve teknolojinin rolü olmak üzere iklim değişikliğine mekansal uyum için öne çıkan konular tespit edilmiştir. İkinci aşamada, öne çıkan konular üzerinden tekrar literatür değerlendirilmesi yapılmış ve akıllı yönetişim kavramı elde edilmiştir. Ardından, mekânsal planlamayı ilişkilendirecek şekilde akıllı yönetişimin kapsamı üzerinden öne çıkan konulardan; Türkiye'de iklim değişikliğine mekansal uyumda akıllı yönetişim yaklaşımının mekansal planlama ilkeleri, katılım, yerel düzey ve teknoloji bağlamında kapsamı tartışılmıştır. Araştırma yöntemi olarak literatür üzerinden betimsel değerlendirmelere olanak sağlayan "içerik analizi” yöntemi kullanılmıştır. Araştırma sonucunda, yerel düzeyde mekansal planlama ilkeleri ve konuya ilişkin aktörler tanımlanmış ancak teknoloji kullanımı ile ilgili eksiklikler tespit edilmiştir. Dolayısıyla, Türkiye'de iklim değişikliğine mekânsal uyumda akıllı yönetişimin potansiyel taşıdığı ve geliştirilmeye açık olduğu saptanmış ancak yeterli kapsamlıı̆̆a henüz ulaşmadığı sonucuna varılmıştır.

Anahtar sözcükler: Akıllı yönetişim; iklim değişikliği; iklim değişikliğine uyum; mekânsal planlama; Türkiye.

\section{ABSTRACT}

The aim of this article is to examine the smart governance in order to increase the effectiveness of spatial planning in cities, which are one of the domains of climate change, and to discuss the current situation of smart governance in Turkey within the framework of climate change adaptation. For the purpose; firstly, the effects of climate change were defined and a two-stage literature review was conducted. In the first stage, in order to understand the relationship between climate change adaptation and spatial planning the indicators by which spatial planning of adaptation to climate change can be evaluated were examined. The prominent issues for spatial adaptation to climate change have been identified as including spatial adaptation policies, governance model, implementation level, participation and the role of technology. In the second stage, literature was reviewed again on the prominent issues and the smart governance was obtained in it. Then, the scope of the smart governance approach in spatial adaptation to climate change in Turkey was discussed through spatial planning principles, participation, local level and technology. The "content analysis" method, which allows descriptive evaluations over the literature, was used as a research method. As a result, spatial planning principles and relevant actors were identified at the local level, but some deficiencies in the use of technology were determined. Therefore, it has been asserted that smart governance in spatial adaptation to climate change in Turkey has the potential and is open to development, but it has not yet reached sufficient scope.

Keywords: Smart governance, climate change, climate change adaptation; spatial planning; Turkey. 


\section{Giriş}

İklim değişikliği, küresel ve yerel düzeyde birçok organizasyonun, hükümet ve yerel yönetimlerin gündeminde yer alan ve etki alanı günden güne artan bir konudur. Her ne kadar iklim değişikliği doğal süreç olarak olağan kabul edilse de; sürekli değişen ve büyüyen kentlerin tetiklediği antropojenik faktörler ile meteorolojik olayların şiddeti, sıklığı ve etkilediği alan artmakta ve iklim değişikliğinin neden olduğu aşırı hava olayları, sıcaklık artışları, kentsel ısı adası (KIA) etkisi, sel ve kuraklık gibi olgular gündelik yaşamı daha fazla etkilemektedir. Bu süreçte kentler ve kentleşmeye bağı işlevler, iklim değişikliği seyrinin daha farklı ortaya çıkmasında hem neden, diğer taraftan da sürdürülebilirlik ve iklim değişikliği etkilerini azaltmada çözüm üretecek alanlar olarak öne çıkmaktadır. Risk azaltma ve uyum politikaları, iklim değişikliğinin olumsuz etkileri bakımından öne çıkan iki temel politika alanıdır (Hope, 2009; Anguelovski ve Carmin, 20I I). İklim değişikliğinde risk azaltma ile ilgili konular, iklim değişikliği üzerinde antropojen kaynaklı etkilerin kontrolüne ve azaltılmasına referans verirken; uyum politikaları ise, iklim değişikliğinin olası etkilerine karşı alınacak önlemler ve uygulamalarla uyumun nasıl sağlanacağını açıklamaktadır (Aşıcı ve Şahin, 20।7). Literatürde yapılan değerlendirmelere göre risk azaltma kapsamında yenilenebilir enerji kaynakları kullanımı ile sera gazı emisyon azaltımı, tüketim-üretim biçimlerinde iyileştirmeler ve benzeri antropojen faktörlerin kontrol altına alınması ve etki azaltma politikaları yer alırken; uyum politikalarında ise su kaynakları yönetimi, atık yönetimi, kıyı alanları ve yeşilmavi altyapı entegrasyonu ile kentlerin iklim değişikliğine dayanıklılığını sağlama gibi sürdürülebilirliğe önem atfeden etki azaltma konuları öne çıkmaktadır (Tol, 2005). Bir başka deyişle, kentsel alanlarda iklim değişikliği ile ilgili her iki politikada önem taşımaktadır. İklim değişikliğinde risk azaltma politikaları, kentleşme pratikleriyle iklim değişikliği üzerinde yaratılan tetikleyici faktörleri kontrol altına almaya ve azaltmaya (karbonu azaltma, tüketimi kontrol altında tutma, Isı adası etkisini azaltma gibi) yönelik iken; iklim değişikliğine uyum politikaları ise, olası iklim değişikliği etkilerine karşı kentlerde uyum kapasitesini artırmaya odaklanmaktadır.

Dolayısıyla, iklim değişikliğinde risk azaltma ve uyum politika alanları, kentlerin iklim değişikliği etkileri ile mücadele edebilme yöntem ve uygulamalarına açıklık kazandırmaktadır (Gossop, 201 I; Zanon ve Verones, 2013). Bu bağlamda öne çıkan vizyoner kent modellerinden düşük karbonlu kent, yeşil kent, iklime duyarlı akıllı kent gibi kentsel gelişme paradigmaları; kentlerde iklim değişikliğine uyum kapasitesinin artırılmasına yönelik uygulamalara odaklanmaktadır (Zanon ve Verones, 20I3; NIUA, 2020). Bu uygulamalarının mekandaki izdüşümü veya etkileri ise mekânsal planlama ile konunun etkileşiminin kurulması gerektiğine işaret etmektedir. Uyum kapasitesinin artırılmasında önemli rolü olduğu ifade edilen mekânsal planlama ile ilgili olarak, kentlerde iklim değişikliğinin etkilerini azaltan ve uyum kapasitesini destekleyen uygulama alanları ile (Wilson, 2006) iklim değişikliğine uyum için işbirlikleri ve katılımcı süreçlerin önemine işaret edilmektedir (Carter vd., 20I5).

Diğer taraftan literatürde iklim değişikliğine mekânsal uyumda karşılaşılan bazı zorluklar olduğunun altı çizilmektedir. İklim değişikliğinin olası etkilerini gözlemlemek için yapılan iklim projeksiyonları 50-100 yıllık uzun erimli senaryoları içerir iken, mekânsal planlar genellikle 10-15 yıllık bir periyodu kapsamaktadır. Dolayısıyla, yapılan mekânsal planların iklim senaryolarını kapsayamadığı ve iklim değişikliğine uyum politikalarının mekânsal planlara entegre edilemediği belirtilmektedir (Fröhlich ve Knieling, 2013). Öte yandan, iklim değişikliğine mekânsal uyum politikaları uzun dönemde etkisini gösterecek maliyetli yatırımlar gerektirdiğinden çoğu hükümet tarafından tercih edilmemektedir (Wilson, 2006). Ülkelerde ekonomik fayda odaklı yönetim sistemi sebebiyle iklim değişikliğine mekânsal uyum için atılan adımlar ve geliştirilen stratejilerin yetersiz olduğuna vurgu yapılmaktadır (Smith, 2010; Calthorpe, 20 I I; Gagnon-Lebrun ve Agrawala, 2007; Davoudi vd., 2009; Ford vd., 20II). Sonuç olarak, mekânsal planların iklim değişikliğinin etkilerini dikkate almadan hazırlanması (Wilson, 2006), yerel düzeyde uygulamadaki belirsizlikler ve entegrasyon sorunu iklim değişikliğine mekânsal uyumun sağlanması önünde bir engel oluşturmaktadır (Wilson, 2006; Greiving ve Fleischhauer, 2012; Hurlimann ve March, 2012; Matthews, Lo ve Bryne, 2015).

Benzer şekilde, Türkiye'de de ulusal düzeyde iklim değişikliğine uyum konusunda yapılan çalışmalarda yerel düzeydeki uygulamalara yol gösterici önerilere yer verildiği görülmektedir (ÇŞB, 20II). Örneğin, ulusal düzeyde üretilen önemli planlardan biri olan İklim Değişikliği Eylem Planında (201 I-2023) (IDEP), yerel düzeye ilişkin yapılan vurgular aşağıda verilmiştir (ÇŞB,20II).

- Yerel düzeyde toplu taşımayı özendirici önlemler alınması

- Yenilenebilir enerji kaynaklarının kullanımı ile ilgili yerel yönetimlerin proje üretmesinin desteklenmesi

- Aktörlerin desteklenerek örgütlenme ve koordinasyonun sağlanması

- Yerel düzeyde organik tarım uygulamalarının desteklenerek tohum bankalarının kurulması

- Yerel yönetimlerce imar planlarının iklime duyarlı yerleşim planları olarak hazırlanması

- Atık yönetim sistemlerinde yerel yönetimlerin teşvikten yararlanmasının sağlanması

- Kent ormanlarının ve diğer yeşil alanların korunması ve geliştirilmesi konusunda yerel yönetimlerin proje hazırlamasının teşvik edilmesi

- İklim değişikliğine uyum kapsamında yerel düzeyde bilinçlendirme çalışmalarının yapılması. 
IDEP'in kapsamında yerel düzeyde uygulama önerileri ve yönetişimin yer aldığı görülmektedir. Ancak yine de, iklim değişikliğine uyumun nasıl mekânsallaşacağı, hangi sektörlerin öncelikli olması gerektiği ve katılım mekanizmasına yönelik belirsizlikler olduğu belirtilmektedir (Şahin 2014; Aşıcı ve Şahin, 2017; Gedikli ve Balaban, 2018). Öte yandan, coğrafik konumu nedeniyle Türkiye'deki çeşitli iklim kuşakları, kentlerde iklim değişikliğine mekânsal uyum kapsamının farklılaşmasını gerektirmektedir (Peker ve Aydın, 2019; Şahin, 2014). Örneğin karasal iklimin hakim olduğu Mardin kenti ile Karadeniz iklimine sahip Trabzon kenti için iklim değişikliğine mekânsal uyum politikaları birbirinden farklı olmalı ve yerin özelliklerine göre şekillenmelidir (Peker ve Aydın, 2019). Dolayısıyla, ulusal düzeyde üretilen iklim değişikliğine uyum planları ve politikalarının yerel düzeyde uygulanabilir olması için kentlere has özelliklerin göz önüne alınarak yerel düzeyde politikalar/ planlar geliştirilmesi ve yerel yönetimlerde katılımcı süreçler ile uygun kararlar alınması önem taşımaktadır.

Uygulamada zorluklar ile karşılaşılsa da iklim değişikliğine uyumda mekânsal planlama, iklim değişikliğinin etkilerini azaltarak uyumu kolaylaştıracak önemli uygulama alanlarından biri olarak görülmektedir (Wilson, 2006; Davoudi vd., 2009; Hurlimann ve March, 2012; Greiving ve Fleischhaurer, 2012). Bu bağlamda, arazi kullanım kararlarının iklime duyarlı bir şekilde yeniden düzenlenmesi uyum için en etkili mekânsal stratejiler arasında yer almaktadır (Wilson, 2006; Fratini vd., 2012; Zanon ve Verones, 2013; Gil-Garcia vd., 2015; Lorenz vd., 2017). Ayrıca sürdürülebilirliğin sağlanması için kaynak tüketimini kontrol altına alması, enerji etkinliğini sağlaması ve doğal çevre ve yapılı çevre arasında dengeyi koruyarak iklim değişikliği etkilerine karşı kriz ortamının oluşmasını engelleyebilme potansiyeli nedeniyle önem atfedilmektedir (Giffinger vd., 2007; Caragliu vd., 20II; Shelton vd., 2015; Peker ve Aydın, 2019).

Diğer yandan, iklim değişikliğine mekânsal uyumun sağlanmasında yönetişim boyutuna da dikkat çekilmektedir (Wilson, 2006; Caragliu vd.,20II; Hurlimann ve March, 2012; Fratini vd., 2012; Zanon ve Verones, 2013; Matthews, Lo ve Byrne 2015; Wamsler vd., 2016; Jeong, 2018). Yönetişim bağlamında teknoloji kullanımının önemli bir yer tuttuğu ve teknolojik araçlar sayesinde (BiT, GIS, Nesnelerin İnterneti gibi) akıllı yönetişimin iklim değişikliğine mekânsal uyumun daha etkin entegre edilebileceğine değinilmektedir. Teknolojinin etkinleştirildiği akıllı yönetişim ile anlık veri akışı sağlanabilmektedir; bu şekilde yerel düzeydeki katılım artırılabilmektedir. Böylece, iklim değişikliğine mekânsal uyumun etkinleştirilmesinde akıllı yönetişim ile kullanıcılar, karar vericiler olurken; yönetim birimleri denetleyici-düzenleyici bir rol üstlenmektedirler (Giffinger vd., 2007; Birkmann vd., 2010; Kourtit vd., 2012; Fröhlich ve Knieling, 2013; Mees vd., 2014; Soomro vd., 2017; Shelton vd., 2015; Hughes vd., 2019).
Yukarıda yapılan değerlendirmeler ışığında bu çalışma kapsamında iklim değişikliğine uyumda mekânsal planlamanın yeri ve akıllı yönetişim tartışılacak ve konuyla ilişkili olarak akıllı yönetişimin Türkiye'de mevcut durumu ve karşı karşıya bulunduğu kısıtlar ortaya koyulacaktır. Konuyu detaylıca ele almak amacıyla geliştirilen araştırma soruları:

I) İklim değişikliğine uyum ve mekânsal planlama ilişkisi akıllı yönetişim çerçevesinde nasıl tariflenebilir?

2) Türkiye'de akıllı yönetişim kapsamında iklim değişikliğine mekânsal uyumdaki yönetişim mekanizmasının mevcut durumu ve eksiklikleri nelerdir?

şeklindedir. Amaca yönelik sorular doğrultusunda, iki aşamalı literatür değerlendirmesi gerçekleştirilmiştir. Araştırmanın ilk adımında iklim değişikliğine uyum ve mekânsal planlama konularında literatürde sorgulama yapılmıştır ve bu araştırmalarda yönetişim, katılım ve teknoloji konularına ilişkin değerlendirmelerin ağılık kazandığı tespit edilmiştir. Bu araştırmalarda akıllı yönetişim öne çıkmış ve ikinci adımda iklim değişikliğine uyum ve mekânsal planlama içerisinden akıllı yönetişim irdelenmiştir. Literatürden içerik analizi yöntemi ile çıkarımlar yapılmış ve son aşamada elde edilen bulgular, Türkiye'de iklim değişikliğine mekânsal uyumda akıllı yönetişimdeki mevcut durumu tartışmak için kullanılmıştır. Çalışmanın özgün yanı, iklim değişikliğine uyumun mekânsal planlama ile nasıl entegre olacağı (yani iklim değişikliğine mekânsal uyumun nasıl sağlanacağı), Türkiye'de akıllı yönetişim vurgusunun mevcutta hangi seviyede olduğu ve nasıl geliştirilmesi gerektiğini ortaya koymasıdır.

\section{Mekânsal Planlamanın İlim Değişikliğine Uyumda Önemi ve Akıllı Yönetişim İlişkisinin Değerlendirilmesi}

Kentler, iklim değişikliğine uyum için politika araçlarının uygulama alanı olarak değerlendirilmektedir. Kentlerin, iklim değişikliğinden kaynaklanan olumsuzluklardan en az derecede etkilenmesi ve daha sürdürülebilir olabilmesi için iklim değişikliğine uyum sağlanması ve mekânsal planlamanın bu konuda bir araç olarak kullanılması öne çıkan konular arasında belirtilmektedir (Carter vd., 2015; Tezer ve Onur, 2015).

İklim değişikliğine uyum (IDU) ve mekânsal planlama (MP) arasındaki ilişkiyi ortaya koymak için bu kavramlar üzerinden SCOPUS'da literatür araştırması yapılmıştır. Bu araştırma iki aşamalı olarak gerçekleştirilmiş ve her aşamada elde edilen yayınlardan hangi kavramların/konuların öne çıktığını anlamak için VosViewer üzerinden değerlendirme yapılmıştır. SCOPUS veri tabanını kullanan VosViewer'da öne çıkan kavramlar, çalı̧manın odağını belirlemiştir.

Birinci aşamada IDU ve MP konularında literatür bütünü içerisinden yapılan çalışmalarda "yönetişim, katılım ve teknoloji" 


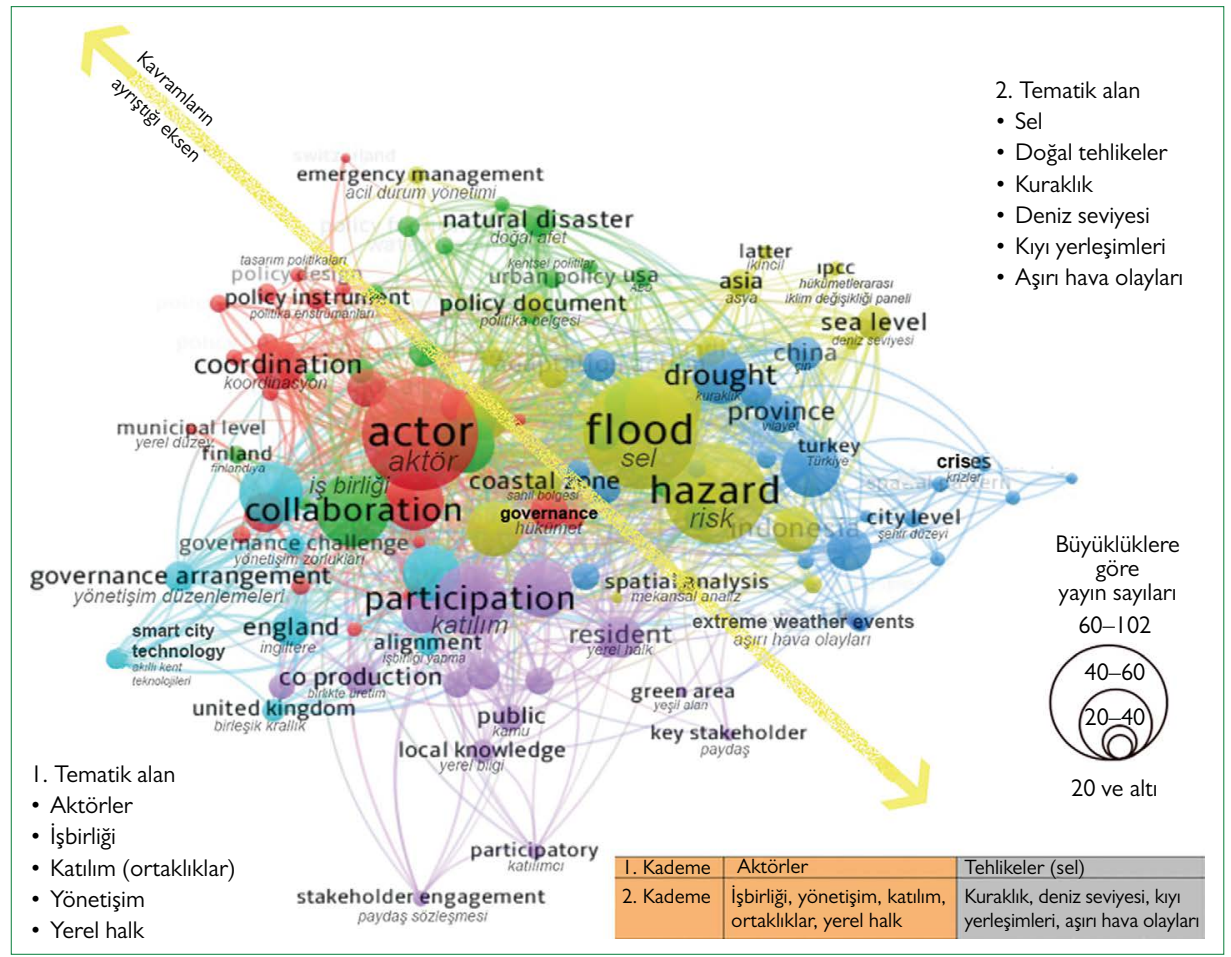

Şekil I. Literatürde iklim değişikliğine uyum ve mekânsal planlama ile ilişkili çalışmalarda öne çıkan kavramsal kümelenmeler.

kavramlarının öne çıktığı görülmüştür (Şekil I). Öne çıkan bu üç kavram üzerinden ikinci aşamaya geçilmiş; iDU ve MP içerisinden yönetişim, katılım ve teknoloji filtresi uygulanarak "akıllı yönetişim” kavramı ön plana çıkmıştır. Her iki aşamada da öne çıkan yayınlar, içerik analizi yöntemi kullanılarak irdelenecektir. Sosyal bilimciler tarafından ortaya koyulan içerik analizi yöntemi, herhangi bir niteliksel araştırma kapsamında objektif ve sistematik değerlendirme yapmayı amaçlayan bir araştırma tekniğidir (Stone vd., 1966; Krippendorf, 2018). Yöntem, kavramların yayınlar içindeki tekrarı üzerinden çalışmayı anlamlandırmayı hedeflemektedir (Janis, 1965). Bu yöntem sayesinde çalışma kapsamındaki her aşamada, öne çıkan temel kavramlar doğrultusunda SCOPUS'ta literatür araştırması yapılarak literatürde ne kadar tekrar ettiği (makalelerde başıı, özet ve anahtar kelimelerde en az 15 kez atıf almış olanlar) üzerinden yayınlar seçilmiştir.

Şekil I'de de görüldüğü gibi IDU ve MP konularına ilişkin toplamda 102 adet çalışma içerisinde "aktör", "tehlike (sel)" I. Kademede öne çıkan kavramlar arasında yer alır iken; 2. kademede ise işbirliği, ortaklıklar, yönetişim, yerel halk, kuraklık ve doğal tehlikeler vurgulanmaktadır. Öte yandan, yayınlar iki tematik alanda yoğunlaşmaktadır. Kavramların ayrıştığı eksen altında kalan birinci tematik alan konunun; katılım, aktörler, yönetişim, ortaklıklar, yerel düzey ve işbirliği ile ilgili yayınlarının yoğunlaştığı alanı gösterir iken; eksen üzerindeki ikinci tematik alan ise tehlike ve sel başta olmak üzere kuraklık, deniz seviyesi, kıyı yerleşimleri, aşırı hava olayları gibi iklim değişikliği ile ilgili doğal tehlikelere odaklanmaktadır.

Çalışma kapsamında, aktörler, katılım, yönetişim ve teknoloji kavramları ile çözüm önerilerinin tartışıldığı kısma odaklanılmaktadır. Böylece, amaç doğrultusunda şekillenen literatür değerlendirmesinin birinci adımı olarak tarif edilen IDU ve MP anahtar kelimelerine ek olarak "yönetişim”, "katılım” ve "teknoloji” anahtar kelimeleri ile araştırma kapsamı daraltılmıştır. 102 çalışma içerisinden IDU ve MP arasındaki ilişkiyi katılım, yönetişim ve teknoloji üzerinden değerlendiren yirmi altı çalışmada (başlık, özet ve anahtar kelimelerde yönetişim, katılım ve yerel düzey konularında en az 15 kez atıf almış makaleler), içerik analizi yöntemi kullanılarak çıkarımlar yapılmıştır. Çalışmalarda iklim değişikliğine mekânsal uyumun nasıl tariflendiği önem kazanmakta ve yönetişim mekanizmasının nasıl kurulduğu, hangi ölçekte çalışmalar yapıldığı, katılımın nasıl sağlandığı ve teknolojinin rolünün ne olduğu ortaya koyulmaktadır.

Mekânsal planlama ile enerji tasarrufunun sağlanması (Zanon ve Verones, 20I3), sel/taşkın etkilerinin azaltılması (Fratini vd., 20I2; Dabrowski vd., 202I), su kaynaklarının yönetimi (Kundzewicz vd., 2019), kentsel sürdürülebilirliğin sağlanması (Kundzewicz vd., 2019; Jeong, 20l8), kaynak tüketiminin kontrol altına alınmasının (Pieterse vd., 2020) iklim değişikliğine uyumda etkili olduğu belirtilmektedir. İncelenen yayınlarda iklim değişikliğine mekânsal uyumun sağlanması için eylemlere yer verilmektedir (Tablo I). 
Tablo I. İklim değişikliğine uyum ve mekânsal planlama ilişkisinde öne çıkan konular

\begin{tabular}{|c|c|c|}
\hline Sayısı & Öne çıkan temel konular & Kaynaklar \\
\hline I & Yeşil alanların korunması, iyileştirilmesi ve artırılması & (Matthews, Lo ve Byrne, 20I5; Carter vd., 2015) \\
\hline 2 & Arazi kullanım kararlarında kamu yararının gözetilmesi & (Carter vd., 2015; Jeong, 2018) \\
\hline 3 & $\begin{array}{l}\text { Yapılı çevrede binaların konumlandırılmasının rüzgar } \\
\text { koridorlarını kesmeyecek şekilde düzenlenmesi }\end{array}$ & (Carter vd., 2015) \\
\hline 4 & $\begin{array}{l}\text { Koruma-kullanma dengesinin gözetilmesi, ekosistem } \\
\text { tabanlı yaklaşım ile kentsel gelişim kararlarının verilmesi }\end{array}$ & (Wamsler vd., 2016) \\
\hline 5 & $\begin{array}{l}\text { Yerleşmelerin hassasiyet düzeylerine göre risk azaltma } \\
\text { planlarının oluşturulması }\end{array}$ & (Dabrowski vd., 202I) \\
\hline 6 & Anlık veri toplama sistemi ile yerleşmelerdeki değişimlerin tespiti & (Jeong, 2018; Shelton vd., 2015) \\
\hline 7 & $\begin{array}{l}\text { Akıllı yönetişim ile iklim değişikliğine yönelik mekansal planlamanın } \\
\text { ilişkilendirilmesi }\end{array}$ & $\begin{array}{l}\text { (Clift, 2003; Birkmann vd., 2010; Kourtit vd., 20I2; } \\
\text { Mees vd., 20I4; Gil-Garcia vd., 20I5; Soomro vd., 20I7; } \\
\text { Okada, 20I8; Peker ve Aydın, 20I9; Yahia vd., 202I). }\end{array}$ \\
\hline
\end{tabular}

İncelenen yayınlarda iklim değişikliğine mekânsal uyumun nasıl sağlanacağı konusunun çeşitlilik gösterdiği tespit edilmiştir. Bazı araştırmalarda kentlerde iklim değişikliğine karşı kırılgan sektörler/alanlar belirlenip bu alanlarda öncelikli olarak mekânsal planların yapılması gerektiğine vurgu yapılırken (Wilson, 2006; Greiving ve Fleischhauer, 2012); Carter ve arkadaşlarına göre (20I5), mekânsal uyumun sağlanması için sektör temelli yaklaşımdan ziyade kentlerde bütüncül bakış açısı ile üretilen mekânsal planların olası iklim değişikliği etkilerine karşı daha fazla koruma sağlayacağı vurgulanmaktadır. Ayrıca, konunun ele alındığı düzeylere dair literatürde farklılaşmalar olduğu görülmektedir. Bazı araştırmacılar iklim değişikliğine mekânsal uyumun sağlanmasının ulusal düzeyde politikalar üreterek (yasalar, veriler gibi) mümkün olacağını savunur iken (Carter vd., 2015; Greiving ve Fleischhauer, 2012) çoğu araştırmacı konunun öncelikle yerel ölçekte anlaşılmasının önemli olduğuna dikkat çekmekte ve yerel ölçekte politika üretmenin mekânsal uyumu hızlandıracağına vurgu yapmaktadır (Wilson, 2006; Caragliu vd., 20I I; Kourtit vd., 20I2; Matthews, Lo ve Byrne, 2015; Lorenz vd., 2017; Jeong, 2018; Kundzewicz vd., 2019; Pieterse vd., 2020; Nguyen ve Do, 2020; Dabrowski vd., 202I). Hem yerel hem ulusal düzeyde eşzamanlı yürütülmesi gerektiği görüşü de çalışmalar arasındadır (Zanon ve Verones, 2013; Wamsler vd., 2016; De Falco vd., 2019; Peker ve Aydın, 2019). Bu bilgiler ışığında, teknoloji kullanımı ve yenilikçi yöntemlerin hem yönetişim modelinin geliştirilmesi hem de katılım mekanizmasının oluşturulmasında önem taşıdığı ve iklim değişikliğine mekânsal uyumu hızlandırıcı etki yarattığının altı çizilmektedir (Fratini vd., 2012; Zanon ve Verones, 2013; Carter vd., 2015; Wamsler vd., 2016; Jeong, 2018; Kundzewicz vd., 2019; Pieterse vd., 2020). Bu değerlendirmelerin ışı̆̆ında, Tablo 2'de IDU ve MP konusundaki çalışmaların içeriğinde öne çıkan konular gösterilmektedir. Bu temalar ile literatürde birinci aşamada elde edilen 26 yayına içerik analizi uygulanmıştır.
Tablo 2'de iklim değişikliğine mekânsal uyumun sağlanabilmesi için mekânsal uyum ilkeleri, yönetişim modeli, uygulama düzeyi, katılım mekanizması (aktörler) ve teknolojinin rolü tanımlanmıştır. Buna göre,

- Iklim değişikliğine mekânsal uyum politikalarında arazi kullanım kararlarının düzenlenmesi, kent içinde açık ve yeşil alanların tasarlanması, kentlere özgü hassas alanlar tespit edilerek öncelikli planlar hazırlanması, müdahaleler için bölgeleme ve etaplamanın yapılması, kaynak tüketiminin kontrol altına alınması, kentsel ısı adası etkisini azaltmaya yönelik yapılı çevrede projeler geliştirildiği örnekler üzerinden tespit edilmiştir.

- Yönetişim modeli çerçevesinde etkin bir yönetişim modeli oluşturulmasının altı çizilmekte ve akıllı yönetişim; uygulamaları hızlandırıcı, kolaylaştırıcı ve denetleyici bir yöntem olarak önerilmektedir.

- Uygulamalarda yerel düzeye vurgu yapılmakta ve iklim değişikliğine mekânsal uyum politikalarının yere özgü olması gerektiğinin altı çizilmektedir.

- Katılım mekanizmasında çeşitli aktörler öne çıkmakta ve çok katmanlı, şeffaf ve adil bir süreç için iklim değişikliğine uyumda kolektif bilinç oluşturmadaki rolüne değinilmekte ve ortaklıklar önerilmektedir.

- Teknoloji kullanımının iklim değişikliğine mekânsal uyumda özellikle katılım mekanizmasını desteklediği ve yerel düzeydeki uygulamalarda verimliliği artıracak e-uygulamalar geliştirerek olası iklim değişikliği etkilerine karşı önlemleri kolaylaştırdığı vurgulanmaktadır.

Literatür araştırmasının birinci aşamasında içerik analizi yöntemi kullanılarak katılım, teknoloji ve yönetişim konularının iDU ve MP kapsamında nasıl ele alındığı değerlendirilmiştir. Akıllı yönetişim ile yerel ölçekte teknolojik araçlardan faydalanan çok 
Tablo 2. İklim değişikliğine uyum ve mekansal planlama ilişkisinde öne çıkan konular

\begin{tabular}{|c|c|c|c|c|c|}
\hline Kaynaklar & $\begin{array}{l}\text { Mekansal uyum } \\
\text { politikaları }\end{array}$ & Yönetişim modeli & $\begin{array}{l}\text { Uygulama } \\
\text { düzeyi }\end{array}$ & $\begin{array}{l}\text { Katılım/ } \\
\text { Aktörler }\end{array}$ & Teknolojinin rolü \\
\hline Wilson, 2006 & $\begin{array}{l}\text { IDU maliyetlerini düşürecek arazi } \\
\text { kullanım kararları, sektörel planlama } \\
\text { anlayışı, yerel yönetimler için yol } \\
\text { gösterici kılavuzlar hazırlanması, } \\
\text { kamusal alanların arttırılması, rüzgar } \\
\text { koridorlarına zarar vermemesi } \\
\text { için yapılı çevrenin düzenlemesi, sel } \\
\text { felaketi için riskli alanların yeşil alan } \\
\text { olarak kullanılması }\end{array}$ & $\begin{array}{l}\text { Şeffaf bir sürece } \\
\text { olanak tanıyan }\end{array}$ & Yerel & $\begin{array}{l}\text { Kamu ve özel sektör } \\
\text { katılımı ile ortaklıkların } \\
\text { desteklenmesi }\end{array}$ & - \\
\hline $\begin{array}{l}\text { Giffinger vd, } \\
2007\end{array}$ & $\begin{array}{l}\text { İklim değişikliğine uyumu hızlandırıcı } \\
\text { bir araç olarak doğal kaynakların } \\
\text { korunmasını önceliğinde arazi kullanım } \\
\text { kararlarının yeniden değerlendirilmesi }\end{array}$ & $\begin{array}{l}\text { Akıllı yönetişim } \\
\text { ile yerel halka } \\
\text { yönelik hizmetlerin } \\
\text { önemsendiği }\end{array}$ & Yerel & $\begin{array}{l}\text { Yerel halk başta } \\
\text { olmak üzere çeşitli } \\
\text { aktörler tanımlanması }\end{array}$ & $\begin{array}{l}\text { BiT ile mekansal } \\
\text { uyum politikalarının } \\
\text { işlerliğinin } \\
\text { denetlenmesi }\end{array}$ \\
\hline $\begin{array}{l}\text { Birkmann vd., } \\
2010\end{array}$ & $\begin{array}{l}\text { Riskli alanların yeşil alan olarak } \\
\text { kullanılması, yeni gelişim alanları için } \\
\text { doğadaki fayda alanlarının kullanılmasını } \\
\text { (tarım alanları, sulak alanlar)engelleyecek } \\
\text { arazi kullanım kararları geliştirilmesi }\end{array}$ & $\begin{array}{l}\text { Akıllı yönetişim ile } \\
\text { koordinasyon ve } \\
\text { işbirliğinin } \\
\text { önemsendiği }\end{array}$ & Yerel & $\begin{array}{l}\text { Özel sektör başta } \\
\text { olmak üzere } \\
\text { çeşitli aktörler } \\
\text { tanımlanması }\end{array}$ & $\begin{array}{l}\text { Mekansal } \\
\text { planlamanın } \\
\text { işlerliğini artırmak } \\
\text { üzere GIS ile arazi } \\
\text { kullanımındaki } \\
\text { değişimlerin anlık } \\
\text { olarak görülmesi }\end{array}$ \\
\hline $\begin{array}{l}\text { Caragliu vd., } \\
2011\end{array}$ & $\begin{array}{l}\text { Doğal kaynakların tespiti, yapılı çevrenin } \\
\text { doğal kaynak alanlarının sınırlarına göre } \\
\text { yeniden değerlendirilmesi }\end{array}$ & $\begin{array}{l}\text { Doğal kaynakların } \\
\text { yönetilmesini } \\
\text { önemseyen akıllı } \\
\text { bir yönetişim }\end{array}$ & Yerel & $\begin{array}{l}\text { Yerel düzeyden } \\
\text { ulusal düzeye } \\
\text { aktörlerin } \\
\text { çeşitlenmesi }\end{array}$ & $\begin{array}{l}\text { Teknolojik } \\
\text { yöntemler ile doğal } \\
\text { kaynaklar } \\
\text { üzerindeki } \\
\text { tehlikenin sinyal } \\
\text { yolu ile tespit } \\
\text { edilmesi }\end{array}$ \\
\hline $\begin{array}{l}\text { Hurlimann } \\
\text { ve March, } \\
2012\end{array}$ & $\begin{array}{l}\text { Yerel yönetimlerin politika üretmesi, } \\
\text { yerin özelliklerine göre öncelikli } \\
\text { hassas alanların tespit edilmesi }\end{array}$ & $\begin{array}{l}\text { Kamu yararın } \\
\text { gözeten ve adil } \\
\text { yönetimi sağlayan }\end{array}$ & Yerel & $\begin{array}{l}\text { Kolektif bilinç } \\
\text { oluşturmak üzere } \\
\text { aktörlerin } \\
\text { çeşitlenmesi }\end{array}$ & $\begin{array}{l}\text { Ortam-çevre } \\
\text { sensörleri ile } \\
\text { hassas alanlardaki } \\
\text { değişikliklerin ilgili } \\
\text { birimlere } \\
\text { aktarımının } \\
\text { sağlanması }\end{array}$ \\
\hline $\begin{array}{l}\text { Kourtit vd., } \\
2012\end{array}$ & $\begin{array}{l}\text { Sosyo-ekonomik ve ekolojik } \\
\text { performansı en üst düzeye çıkarmak } \\
\text { için kentlerde yapılı çevreye dair } \\
\text { kısıtlamalar getirilmesi (kat yüksekliği, } \\
\text { konumlandırma gibi) }\end{array}$ & $\begin{array}{l}\text { Akıllı yönetişim ile } \\
\text { açık fikirli ve şeffaf } \\
\text { yönetişim }\end{array}$ & Yerel & $\begin{array}{l}\text { Kolektif bilinç } \\
\text { oluşturmak üzere } \\
\text { aktörlerin } \\
\text { çeşitlenmesi }\end{array}$ & $\begin{array}{l}\text { Anlık veri toplama } \\
\text { ile yapılı çevredeki } \\
\text { olumsuz koşulların } \\
\text { tespit edilmesi }\end{array}$ \\
\hline $\begin{array}{l}\text { Fratini vd., } \\
2012\end{array}$ & $\begin{array}{l}\text { Aşırı hava olaylarına göre arazi kullanım } \\
\text { kararlarının yeniden gözden geçirilmesi, } \\
\text { sel felaketine karşı teknik optimizasyon, } \\
\text { standartlar ve yönergelerin ortaya } \\
\text { konması, kentsel drenaj sistemlerinin } \\
\text { kurulması }\end{array}$ & $\begin{array}{l}\text { Şeffaf bir sürece } \\
\text { olanak tanıyan }\end{array}$ & Yerel & $\begin{array}{l}\text { Temel aktör olarak } \\
\text { şehir plancıları, su } \\
\text { bilimcileri ve sigorta } \\
\text { şirketlerinin seçilmesi }\end{array}$ & $\begin{array}{l}\text { Anlık verinin } \\
\text { toplanmasına } \\
\text { olanak sağlayan } \\
\text { sistemlerin } \\
\text { kentlerde riskli } \\
\text { bölgelere }\end{array}$ \\
\hline
\end{tabular}


Tablo 2 (devamı). İklim değişikliğine uyum ve mekansal planlama ilişkisinde öne çıkan konular

\begin{tabular}{|c|c|c|c|c|c|}
\hline Kaynaklar & $\begin{array}{l}\text { Mekansal uyum } \\
\text { politikaları }\end{array}$ & Yönetişim modeli & $\begin{array}{l}\text { Uygulama } \\
\text { düzeyi }\end{array}$ & $\begin{array}{l}\text { Katılım/ } \\
\text { Aktörler }\end{array}$ & Teknolojinin rolü \\
\hline & & & & & $\begin{array}{l}\text { yerleştirilmesi, } \\
\text { yönetişimde } \\
\text { şeffaflığı sağlamak } \\
\text { üzere bilgilerin } \\
\text { sürekli } \\
\text { güncellenmesi }\end{array}$ \\
\hline $\begin{array}{l}\text { Greiving ve } \\
\text { Fleischhaurer, } \\
2012\end{array}$ & $\begin{array}{l}\text { Ulaşım, kıyı alanları, sanayi, turizm ve } \\
\text { enerji sektörlerinde mekansal uyum için } \\
\text { kriterler belirlenmesi, etaplar halinde } \\
\text { uygulamaların yapılması, su kıtlığı ve sel } \\
\text { gibi aşırı hava olaylarına karşı arazi } \\
\text { kullanımında değişiklikler yapılması }\end{array}$ & $\begin{array}{l}\text { Akıllı yönetişim ile } \\
\text { uygulamayı } \\
\text { kolaylaştırıcı araç }\end{array}$ & Ulusal & $\begin{array}{l}\text { Kollektif bilinç } \\
\text { oluşturmak üzere } \\
\text { aktörlerin } \\
\text { çeşitlenmesi }\end{array}$ & $\begin{array}{l}\text { Anlık veri paylaşımı } \\
\text { ile arazi } \\
\text { kullanımındaki } \\
\text { değişikliklerin } \\
\text { gözlenmesi }\end{array}$ \\
\hline $\begin{array}{l}\text { Zanon ve } \\
\text { Verones, } \\
2013\end{array}$ & $\begin{array}{l}\text { Arazi kullanım kararlarında yol } \\
\text { hiyerarşisinin gözden geçirilmesi, yol } \\
\text { kenarı ağaçlandırma çalışmalarının } \\
\text { arttıııması, bina yüksekliklerinin } \\
\text { azaltııması, kompakt kent formu önerisi } \\
\text { ve toplu taşımanın yaygınlaştırıması için } \\
\text { bilinçlendirme çalışmalarının yapııması }\end{array}$ & $\begin{array}{l}\text { Yasal düzenlemeler } \\
\text { ile uygulamayı } \\
\text { kolaylaştırıcı araç }\end{array}$ & $\begin{array}{l}\text { Ulusal } \\
\text { Yerel }\end{array}$ & $\begin{array}{l}\text { Kamu ve özel } \\
\text { ortaklığına dayanan } \\
\text { katılım ortamının } \\
\text { sağlanması }\end{array}$ & $\begin{array}{l}\text { Yenilikçi termal ve } \\
\text { fotovoltaik paneller } \\
\text { aracılı̆̆ıla } \\
\text { yenilenebilir } \\
\text { kaynaklardan } \\
\text { yerinde enerji } \\
\text { üretimini sağlayarak } \\
\text { enerji tedarik ve } \\
\text { dağıtımını } \\
\text { kolaylaştırır }\end{array}$ \\
\hline $\begin{array}{l}\text { Fröhlich ve } \\
\text { Knieling, } \\
2013\end{array}$ & $\begin{array}{l}\text { Kentsel sistemlerde verimlilik sağlamak } \\
\text { üzere yapılı çevre, doğal çevre ve atıl } \\
\text { alanların tespiti }\end{array}$ & $\begin{array}{l}\text { Akıllı yönetişim ile } \\
\text { şeffaf bir sürece } \\
\text { olanak tanıyan }\end{array}$ & Yerel & $\begin{array}{l}\text { Yerel düzeyden ulusal } \\
\text { düzeye çeşitli aktörler } \\
\text { tanımlanması }\end{array}$ & $\begin{array}{l}\text { BiT ile kentsel atıl } \\
\text { alanların tespit } \\
\text { edilmesi }\end{array}$ \\
\hline $\begin{array}{l}\text { Mees vd., } \\
2014\end{array}$ & $\begin{array}{l}\text { Yağmur suyunun kullanılabilirliğini } \\
\text { artırmak için yeşil çatı uygulamalarının } \\
\text { yaygınlaştırılması, sel felaketine karşı } \\
\text { dayanıklı konut üretiminin sağlanması }\end{array}$ & $\begin{array}{l}\text { Akıllı yönetişim } \\
\text { kapsamında maliyet } \\
\text { ve faydaların } \\
\text { ortaya koyan ve } \\
\text { katılımı önemseyen }\end{array}$ & Yerel & $\begin{array}{l}\text { Yerel halk, özel sektör, } \\
\text { kamu sektörü ve } \\
\text { STK'ların tanımlanması }\end{array}$ & $\begin{array}{l}\text { E- yönetişime } \\
\text { olanak sağlayan } \\
\text { teknolojik } \\
\text { altyapının kurulması }\end{array}$ \\
\hline $\begin{array}{l}\text { Matthews, } \\
\text { Lo ve Byrne } \\
2015\end{array}$ & $\begin{array}{l}\text { Yeşil altyapının kurulması için yeşil } \\
\text { alanların arttırılması ve kullanımının } \\
\text { desteklenmesi }\end{array}$ & $\begin{array}{l}\text { Şeffaf bir sürece } \\
\text { olanak tanıyan }\end{array}$ & Yerel & $\begin{array}{l}\text { İklim uzmanları, şehir } \\
\text { plancıları, politika } \\
\text { yapıcılar ile ulusal } \\
\text { düzeyde katılımcılar, } \\
\text { üniversiteler, yerel } \\
\text { yönetimler ve } \\
\text { STK'ların tanımlanması }\end{array}$ & $\begin{array}{l}\text { Teknolojik altyapı } \\
\text { ile (web tabanlı } \\
\text { uygulamalar) karar } \\
\text { anketlerine erişim } \\
\text { sağlanması }\end{array}$ \\
\hline $\begin{array}{l}\text { Carter vd., } \\
2015\end{array}$ & $\begin{array}{l}\text { Yeşil alanların korunması ve iyileştirilmesi, } \\
\text { binaların konumu ve tasarımı }\end{array}$ & $\begin{array}{l}\text { Esnek bir şekilde } \\
\text { yasa ve önetmelik- } \\
\text { lerde değişiklikleri } \\
\text { yapılmasına olanak } \\
\text { tanıyan }\end{array}$ & $\begin{array}{l}\text { Ulusal } \\
\text { Yerel }\end{array}$ & $\begin{array}{l}\text { Kolektif bilinç } \\
\text { oluşturmak üzere } \\
\text { aktörlerin çeşitlenmesi }\end{array}$ & $\begin{array}{l}\text { BiT tabanlı } \\
\text { sistemlerle anlık } \\
\text { veriyi toplayarak } \\
\text { mekansal uyumun } \\
\text { kolaylaştırılması }\end{array}$ \\
\hline $\begin{array}{l}\text { Shelton vd, } \\
2015\end{array}$ & $\begin{array}{l}\text { Kaynak tüketimini kısıtlamak üzere } \\
\text { kompakt bir kent yerleşimi önerisi, } \\
\text { ekonomik getiri sağlayan sektörlerin }\end{array}$ & $\begin{array}{l}\text { Akıllı yönetişim ile } \\
\text { uygulamayı } \\
\text { kolaylaştırıcı araç }\end{array}$ & Yerel & $\begin{array}{l}\text { Yerel düzeyde aktörler } \\
\text { belirlenmesi }\end{array}$ & $\begin{array}{l}\text { GIS ile mekansal } \\
\text { veri kaynakları } \\
\text { oluşturarak kent }\end{array}$ \\
\hline
\end{tabular}


Tablo 2 (devamı). İklim değişikliğine uyum ve mekansal planlama ilişkisinde öne çıkan konular

\begin{tabular}{|c|c|c|c|c|c|}
\hline Kaynaklar & $\begin{array}{l}\text { Mekansal uyum } \\
\text { politikaları }\end{array}$ & Yönetişim modeli & $\begin{array}{l}\text { Uygulama } \\
\text { düzeyi }\end{array}$ & $\begin{array}{l}\text { Katılım/ } \\
\text { Aktörler }\end{array}$ & Teknolojinin rolü \\
\hline & $\begin{array}{l}\text { yer seçimlerinin yeniden gözden } \\
\text { geçirilmesi }\end{array}$ & & & & $\begin{array}{l}\text { dokusundaki } \\
\text { değişimlerin tespit } \\
\text { edilmesi }\end{array}$ \\
\hline $\begin{array}{l}\text { Gil-Garcia } \\
\text { vd., } 2015\end{array}$ & $\begin{array}{l}\text { Bisiklet yollarının yapılması, arazi kullanım } \\
\text { kararlarında su kaynaklarının korunmasına } \\
\text { özen gösterilmesi }\end{array}$ & $\begin{array}{l}\text { Akıllı yönetişim ile } \\
\text { ortaklıkların } \\
\text { önemsendiği şeffaf } \\
\text { bir sürece olanak } \\
\text { sağlayan }\end{array}$ & Yerel & $\begin{array}{l}\text { Yerel halk, özel sektör, } \\
\text { kamu sektörü ve } \\
\text { STK'ların tanımlanması }\end{array}$ & $\begin{array}{l}\text { E- yönetişime } \\
\text { olanak sağlayan } \\
\text { teknolojik } \\
\text { altyapının } \\
\text { kurulması }\end{array}$ \\
\hline $\begin{array}{l}\text { Wamsler vd., } \\
2016\end{array}$ & $\begin{array}{l}\text { Koruma-kullanma dengesini gözeten } \\
\text { ekosistem tabanlı uyum vizyonu ile yeşil } \\
\text { altyapının kurulması. Biyoçeşitliliğin } \\
\text { korunmasına yönelik hassas alanların } \\
\text { tespit edilmesi }\end{array}$ & $\begin{array}{l}\text { Uygulamayı } \\
\text { kolaylaştırıcı araç }\end{array}$ & Yerel & $\begin{array}{l}\text { Kolektif bilinç } \\
\text { oluşturmak üzere } \\
\text { aktörlerin çeşitlenmesi }\end{array}$ & $\begin{array}{l}\text { Ekosistem temelli } \\
\text { yaklaşımı } \\
\text { destekleyecek } \\
\text { teknolojik altyapı } \\
\text { ile uygulamaların } \\
\text { hızlandırılması }\end{array}$ \\
\hline $\begin{array}{l}\text { Lorenz vd., } \\
2017\end{array}$ & $\begin{array}{l}\text { İklim projeksiyonları yaparak arazi } \\
\text { kullanım kararlarının yeniden gözden } \\
\text { geçirilmesi }\end{array}$ & $\begin{array}{l}\text { Yasal düzenlemeler } \\
\text { ile uygulamayı } \\
\text { denetleyici araç }\end{array}$ & Yerel & $\begin{array}{l}\text { Yerel düzeyden ulusal } \\
\text { düzeye çeşitli aktörler } \\
\text { tanımlanması }\end{array}$ & $\begin{array}{l}\text { BIT ve Nesnelerin } \\
\text { İnterneti ile } \\
\text { mekansal uyum } \\
\text { politikalarının } \\
\text { işlerliğini denetler }\end{array}$ \\
\hline $\begin{array}{l}\text { Soomro vd., } \\
2017\end{array}$ & $\begin{array}{l}\text { Ulaşıma dair eylemler ile arazi } \\
\text { kullanımının yeniden gözden geçirilmesi }\end{array}$ & $\begin{array}{l}\text { Akıllı yönetişim ile } \\
\text { şeffaf bir katılım } \\
\text { süreci }\end{array}$ & Yerel & $\begin{array}{l}\text { Yerel düzeyden ulusal } \\
\text { düzeye çeşitli aktörler } \\
\text { tanımlanması }\end{array}$ & $\begin{array}{l}\text { BiT ile kentsel } \\
\text { büyüme için 3B } \\
\text { etkileşimli } \\
\text { görselleştirme ve } \\
\text { simülasyon } \\
\text { teknikliklerinin } \\
\text { kullanılması }\end{array}$ \\
\hline Jeong, 2018 & $\begin{array}{l}\text { Yerin koşullarına göre arazi kullanım } \\
\text { kararlarının yeniden düzenlenmesi, } \\
\text { kamu yararını ön planda tutan ve } \\
\text { kamusal alanları arttırmayı hedefleyen } \\
\text { mekansal kararların verilmesi }\end{array}$ & $\begin{array}{l}\text { Kurumsal } \\
\text { yapılanmayı } \\
\text { sağlayacak bir araç }\end{array}$ & Yerel & $\begin{array}{l}\text { Kamu sektörü } \\
\text { öncülüğünde çeşitli } \\
\text { aktörler tanımlanması }\end{array}$ & $\begin{array}{l}\text { Anlık veri paylaşımı } \\
\text { ile sürdürülebilir } \\
\text { arazi kullanımının } \\
\text { desteklenmesi, } \\
\text { aktörlerin tespit } \\
\text { edilmesi }\end{array}$ \\
\hline Okada, 2018 & $\begin{array}{l}\text { Risklere duyarlı eylem planlarının } \\
\text { hazırlanması, kentsel dönüşüm } \\
\text { uygulamalarında iklim değişikliği } \\
\text { etkilerinin önceliklendirilmesi }\end{array}$ & $\begin{array}{l}\text { Akıllı yönetişim ile } \\
\text { uygulamayı } \\
\text { kolaylaştırıcı araç }\end{array}$ & Yerel & $\begin{array}{l}\text { Kollektif bilinç } \\
\text { oluşturmak üzere } \\
\text { aktörlerin çeşitlenmesi }\end{array}$ & $\begin{array}{l}\text { Akıllı telefonlar } \\
\text { aracılığıyla web'e } \\
\text { her yerde erişim } \\
\text { sağlanmasıyla riskli } \\
\text { alanların tespit } \\
\text { edilmesi }\end{array}$ \\
\hline $\begin{array}{l}\text { Peker ve } \\
\text { Aydın, } 2019\end{array}$ & $\begin{array}{l}\text { Su kaynakları yönetimi, yeşil ve açık } \\
\text { alanların yönetimi, kentsel sağık, olası } \\
\text { risklerin tespiti, toplumsal farkındalık } \\
\text { konularına ilişkin arazi kullanımında } \\
\text { düzenlemeler yapılması. Hava kalitesi } \\
\text { ölçüm istasyonlarının kurulması, yerel } \\
\text { düzeyde yağmur suyu toplama, }\end{array}$ & $\begin{array}{l}\text { Akıllı yönetişim ile } \\
\text { uygulamayı } \\
\text { kolaylaştırıcı araç }\end{array}$ & Yerel & $\begin{array}{l}\text { Yerel düzeyden ulusal } \\
\text { düzeye çeşitli } \\
\text { aktörlerin teknolojik } \\
\text { tanımlanması }\end{array}$ & $\begin{array}{l}\text { E-yönetişime } \\
\text { olanak sağlayan } \\
\text { altyapının kurularak } \\
\text { her düzeyde } \\
\text { katılımın sağlanması } \\
\text { ve yüksek } \\
\text { çözünürlüklü }\end{array}$ \\
\hline
\end{tabular}


Tablo 2 (devamı). İklim değişikliğine uyum ve mekansal planlama ilişkisinde öne çıkan konular

\begin{tabular}{|c|c|c|c|c|c|}
\hline Kaynaklar & $\begin{array}{l}\text { Mekansal uyum } \\
\text { politikaları }\end{array}$ & Yönetişim modeli & $\begin{array}{l}\text { Uygulama } \\
\text { düzeyi }\end{array}$ & $\begin{array}{l}\text { Katılım/ } \\
\text { Aktörler }\end{array}$ & Teknolojinin rolü \\
\hline & $\begin{array}{l}\text { depolama, arıtma ve kullanma } \\
\text { sistemlerinin oluşturulması. }\end{array}$ & & & & $\begin{array}{l}\text { iklim verisinin } \\
\text { toplanması }\end{array}$ \\
\hline $\begin{array}{l}\text { Kundzewicz } \\
\text { vd., } 2019\end{array}$ & $\begin{array}{l}\text { Kentsel su kullanımının tespit edilmesi, } \\
\text { kayıp-kaçak su oranının tespiti ile } \\
\text { kaynakların verimli kullanımının } \\
\text { sağlanması, arazi kullanımında } \\
\text { değişiklikler yapılması, bölgeleme ile } \\
\text { öncelikli müdahale alanlarının belirlenmesi }\end{array}$ & $\begin{array}{l}\text { Kentsel su } \\
\text { yönetimine } \\
\text { katkı sağlayan } \\
\text { araç }\end{array}$ & Yerel & $\begin{array}{l}\text { İklim bilimciler başta } \\
\text { olmak üzere çeşitli } \\
\text { aktörler tanımlanması }\end{array}$ & $\begin{array}{l}\text { GIS ile sel odaklı } \\
\text { iklim senaryolarının } \\
\text { hazırlanması }\end{array}$ \\
\hline $\begin{array}{l}\text { Nguyen ve } \\
\text { Do, } 2020\end{array}$ & $\begin{array}{l}\text { Dere koridorlarının korunması, taşkın } \\
\text { riskli alanların yeşil alana çevrilmesi ve } \\
\text { kompakt kent modeli ilkeleri uyarlanması }\end{array}$ & $\begin{array}{l}\text { Akıllı yönetişim ile } \\
\text { uygulamayı } \\
\text { kolaylaştırıcı araç }\end{array}$ & Yerel & $\begin{array}{l}\text { Yerel halk ve kamu } \\
\text { kurumları başta olmak } \\
\text { üzere çeşitli aktörler } \\
\text { tanımlanması }\end{array}$ & $\begin{array}{l}\text { E-uygulamalar } \\
\text { sayesinde her } \\
\text { kararın katılımcı } \\
\text { ortamda üretilmesi } \\
\text { ve anlık veri } \\
\text { akışının } \\
\text { sağlanmasıyla } \\
\text { büyük kentsel } \\
\text { yönetim } \\
\text { birimlerinden anlık } \\
\text { çözüm odaklı } \\
\text { yönetim modeline } \\
\text { geçilmesi }\end{array}$ \\
\hline $\begin{array}{l}\text { Pieterse vd., } \\
2020\end{array}$ & $\begin{array}{l}\text { Kaynak tüketimini kontrol altına alacak } \\
\text { arazi kullanımın hazırlanması, riskli } \\
\text { alanların kamusal alanlara dönüşümünün } \\
\text { sağlanması }\end{array}$ & $\begin{array}{l}\text { Uygulamayı } \\
\text { kolaylaştırıcı araç }\end{array}$ & Yerel & $\begin{array}{l}\text { Şehir plancıları başta } \\
\text { olmak üzere çeşitli } \\
\text { aktörler tanımlanması }\end{array}$ & $\begin{array}{l}\text { Akıllı kent modeli } \\
\text { ile kentsel } \\
\text { sistemlerdeki } \\
\text { işleyişi } \\
\text { kolaylaştırmak } \\
\text { üzere teknolojik } \\
\text { altyapının kurulması }\end{array}$ \\
\hline $\begin{array}{l}\text { Dabrowski } \\
\text { vd., } 2021\end{array}$ & $\begin{array}{l}\text { Sel felaketi odağında arazi kullanım } \\
\text { kararlarının yeniden değerlendirilmesi, } \\
\text { öncelikle kamu kurumlarının önlem } \\
\text { planları oluşturması, ulaşım türlerinin } \\
\text { çeşitlenmesi }\end{array}$ & $\begin{array}{l}\text { Uygulamayı } \\
\text { kolaylaştırıcı araç }\end{array}$ & Yerel & $\begin{array}{l}\text { Yerel halk ve kamu } \\
\text { kurumları başta olmak } \\
\text { üzere çeşitli aktörler } \\
\text { tanımlanması }\end{array}$ & $\begin{array}{l}\text { Sel için erken uyarı } \\
\text { sistemleri ile } \\
\text { yöneticilerin ve } \\
\text { halkın } \\
\text { bilgilendirilmesi, } \\
\text { anlık veri paylaşımı } \\
\text { sayesinde ölçülen } \\
\text { su seviyesinin } \\
\text { görülmesi }\end{array}$ \\
\hline $\begin{array}{l}\text { Yahia vd., } \\
2021\end{array}$ & $\begin{array}{l}\text { Sürdürülebilir kentsel gelişme için mevcut } \\
\text { dokuda boşlukların doldurulması, yapılı } \\
\text { çevrenin kontrol altına alınması amacıyla } \\
\text { yeşil alanların artırılması. }\end{array}$ & $\begin{array}{l}\text { Akıllı yönetişim ile } \\
\text { teknolojiyi } \\
\text { kullanarak işbirlikçi } \\
\text { ağlar oluşturan }\end{array}$ & Yerel & $\begin{array}{l}\text { Kolektif bilinç } \\
\text { oluşturmak üzere } \\
\text { aktörlerin çeşitlenmesi }\end{array}$ & $\begin{array}{l}\text { Bulut bilişim ile } \\
\text { katılımcıların } \\
\text { bilgilerinin } \\
\text { kaydedilmesiyle } \\
\text { verimliliğin } \\
\text { artırılması }\end{array}$ \\
\hline
\end{tabular}




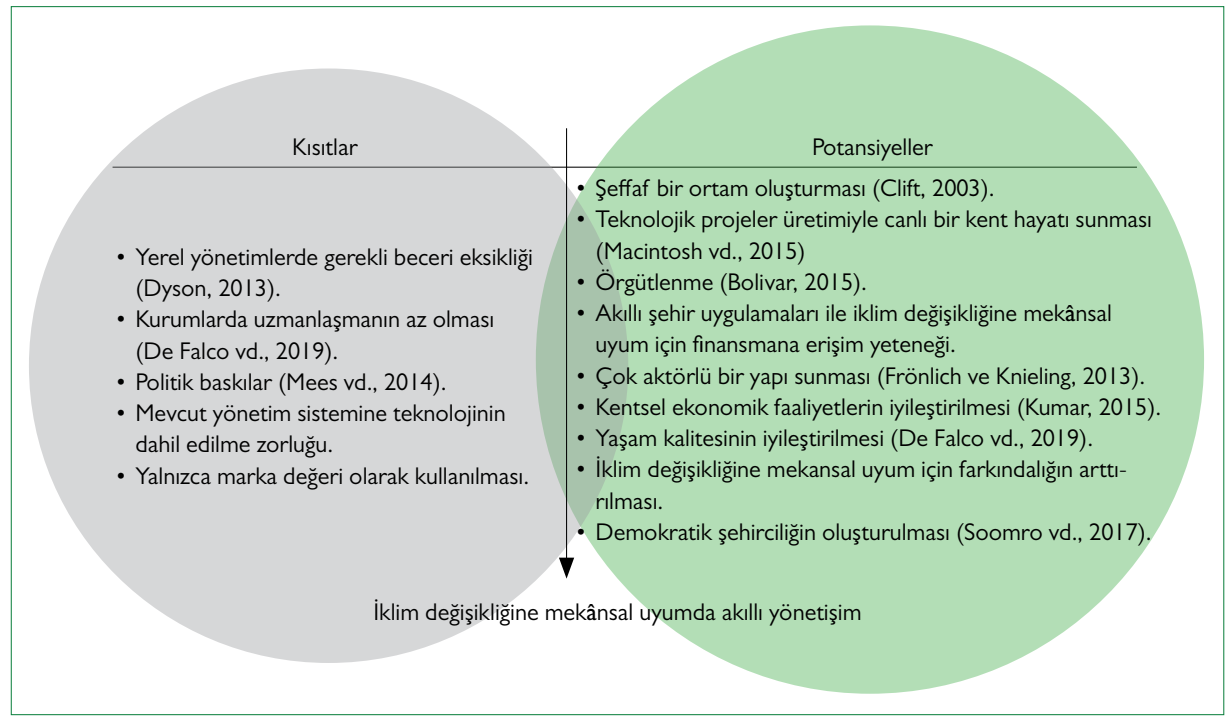

Şekil 2. Akıllı yönetişimde potansiyeller ve kısıtlar.

katmanlı bir yaklaşımın iklim değişikliğine mekânsal uyumda önemli olduğu sonucuna varılmıştır (Şekil 2). Şekil 2'de görülebileceği üzere akıllı yönetişim, iklim değişikliğine mekânsal uyumda önemli potansiyeller taşımaktadır. Şeffaflık, çok aktörlü katılım mekanizması, örgütlenme ve teknoloji kullanımının kentsel sektörlere entegrasyonu gibi birçok potansiyel taşıyan akıllı yönetişim için yeterli altyapının ve uzmanlaşmanın olmayışı gibi kısıtlar da vardır. Ancak sahip olduğu potansiyel ile yenilikçi yaklaşımlar getirebileceğinden çalışmanın üçüncü bölümünde iklim değişikliğine mekânsal uyum için akıllı yönetişim ele alınacaktır.

\section{3. İklim Değişikliğine Mekânsal Uyumda Akıllı Yönetişim}

İklim değişikliğine mekânsal uyumun sağlanması ve uygulanabilir olmasında akıllı yönetişim öne çıkmaktadır (Bulkeley, 20 I0; Greiving ve Fleischhauer, 2012; Matthews, Lo ve Byrne, 2015; Soomro vd., 2017; Yao vd., 2019; Aijaz, 2020; Gustafsson ve Mignon, 2020; Tzioutziou ve Xenidis, 202I). Buna göre, amaca yönelik literatür değerlendirmesinin ikinci aşaması olarak tarif edilen IDU ve MP anahtar kelimeleri içerisinden yönetişim, katılım ve teknolojiye ek olarak "akıllı yönetişim” anahtar kelimesi ile arama yapılmıştır. Illk olarak VosViewer programı ile akıllı yönetişim bağlamında öne çıkan konulara yer verilmiş ve çalışmanın odağı tarif edilmiştir (Şekil 3). Ardından, SCOPUS üzerinden konuya ilişkin literatür taranarak ortaya çıkan 17 makale irdelenecektir.

Yapılan literatür araştırmasına göre Şekil 3'te IDU ve MP konularını içeren çalışmalarda akıllı yönetişimin ilişkili olduğu temalar/kavramlar görülmektedir. Şekilden de anlaşılabileceği gibi kavramlar üç kademeye ayrılmıştır. I. kademede akıllı yönetişim öne çıkarken; 2 . kademede ise teknoloji, veri, yerel düzey ve e-yönetişimin üzerinde durulmuştur. 3. kademede de dayanıklılık, sürdürülebilir gelişme, toplum, yerel katılım, aktörler/paydaşlar, BiT ve bürokrasi gibi kavramlar öne çıkmıştır. I.ve 2. kademedeki kavramlar, akıllı yönetişimin sağlanmasına yönelik araçlara ilişkin yayınlarda yer alır iken; 3. kademedekiler ise akıllı yönetişimi destekleyici araçlara yer verilen çalışmaları içermektedir. Birbirini tamamlayan çalışmalar içerisinden akıllı yönetişimin anlaşılmasında önem taşıdığından ilk iki kademe çalışma kapsamına dahil edilmiş ve akıllı yönetişime dair literatür değerlendirmesinin ikinci adımına geçilmiştir.

Akıllı yönetişim, en genel tanımı ile kentlerde mevcut yönetişim sisteminin teknolojik araçlar kullanılarak etkinleştirilmesi olarak tarif edilmektedir (Praharaj vd., 2018). Akıllı yönetişim, iklim değişikliğine mekânsal uyum için karmaşık kentsel sistemlerin (ulaşım, eğitim, sağlık, hizmet gibi) işleyişinin geliştirilmesinde, çok aktörlü katılımın sağlanmasında ve iklim değişikliği etkilerine karşı mekânsal önlemlerin alınmasını kolaylaştırıcı olarak ifade edilmektedir (Tzioutziou ve Xenidis, 202I; Arafah ve Winarso, 2017; Yao vd., 2019; Johnson, Robinson ve Philpot, 2020; Karvonen, 2020; Aijaz, 2020). Ayrıca, konvansiyonel yönetişim mekanizmalarının günümüz koşullarının gerekliliklerini yeterince karşılamadığı ve akıllı yönetişimin uygulanmadığı yerleşmelerin iklim değişikliğinden daha fazla etkilenebileceğine değinilmektedir (Kumar, 20I3; Ahammad, 20I I). Diğer taraftan, iklim değişikliği etkilerinde olduğu gibi geleceğe yönelik belirsizliklere akıllı yönetişim ile daha etkin uyum gösterilebileceği belirtilmektedir. Örneğin, Tayland, Filipinler ve Afrika'daki ülkelerde yapılan çalışmalarda akıllı yönetişime geçilemediğinden iklim değişikliği sebebiyle meydana gelen sellerin sonuçlarının daha ağır olduğuna değinilmekte ve anlık veri paylaşımının olmayışı, erken uyarı sensörlerinin kullanılmayışı, halkı sürece dahil etmeyerek farkındalık yaratılmaması sebepleri ile mekânsal uyum politikalarını sekteye uğrattığına değinilmektedir (Daniere ve Garschagen, 2019; Filho vd., 2019). Dolayısıyla, akıllı yönetişimin iklim değişikliği etkilerini azaltıcı rolü olduğuna dikkat çekilmektedir. 


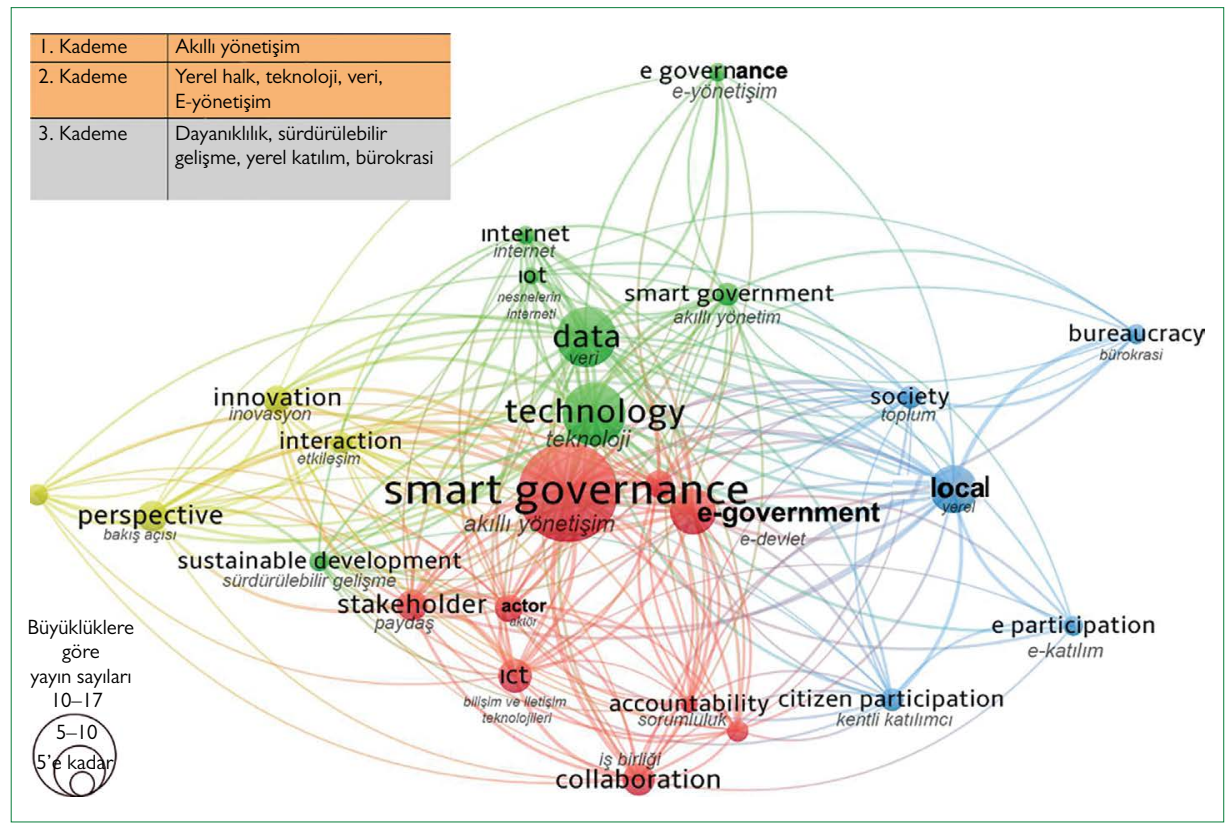

Şekil 3. Literatürde iklim değişikliğine uyum ve mekânsal planlamada akıllı yönetişim ile ilişkili çalışmalarda öne çıkan kavramsal kümelenmeler.

Öte yandan akıllı kent bileşenlerinden biri olarak akıllı yönetişim; karar verme mekanizmasının özel çıkar gruplarından ve devlet kontrolünden çıkarılarak vatandaşlara, topluluklara ve sosyal inovasyona kaydırıması olarak tanımlanmaktadır (Cardullo ve Kitchin, 2019). Akıllı kentin uygulanabilir olmasında, katılımcı demokrasi ortamı için dijital bir altyapı sunan, kentler tarafından finanse edilen ve açık bir topluluk tarafından yönetilen ortamlar oluşturarak iklim değişikliğine karşı mekânsal uyumun sağlanmasına katkı sağlamaktadır. Dolayısıyla, akıllı yönetişimde kentlilerin/yerel halkın rolü açıkça tanımlanmalıdır. Ayrıca, vatandaş katılımının yanı sıra teknolojik çözümcülüğü de teşvik eden akıllı yönetişim sayesinde teknoloji kullanımıyla (uzaktan algılama, GIS tabanlı uygulamalar gibi) karar verme süreçlerinde demokratikleşme sağlanabilmektedir. Bu bağlamda akıllı yönetişim, aşamalı olarak yönetilen fikir birliği olarak tanımlanmaktadır (MacLeod, 20II). Buna göre, iklim değişikliğine mekânsal uyumun sağlanmasına yönelik uygulamalarda vatandaş merkezli akıllı yönetişim yaklaşımı ile farkındalık yaratılarak aşamalar tanımlanabilmektedir. Örneğin, iklim değişikliğine mekânsal uyum için kentlerde yeşil altyapının (yeşil ağ) oluşturulmasında akıllı yönetişim bir araç olarak kullanılabilmektedir. Yaşam kalitesinin ve kentlerde çekiciliğinin artırılması ve enerji tasarrufunun sağlanmasında rol oynayan yeşil altyapı, kentlilerin katılımı sağlanarak sistematik bir şekilde akıllı yönetişim sayesinde kurulabilmektedir (Cardullo ve Kitchin, 2019). Bu bağlamda, iklim değişikliğine mekânsal uyumda akıllı yönetişim kapsamında literatürde tartışılan konular aşağıda verilmektedir (Tablo 3).

Tablo 3. Akıllı yönetişimde öne çıkan konular

\begin{tabular}{lll}
\hline Sayısı & Öne çıkan temel konular & Kaynaklar \\
\hline I & İşbirliği, ağlar ve katılım & $\begin{array}{l}\text { (Corfee-Morlot vd., 2009; Pereira vd., 20I8; Hughes vd., 20I9; Israilidis, Odusanya } \\
\text { ve Mazhar, 20I9; Gustafsson ve Mignon, 2020; Castán Broto ve Westman, 2020; } \\
\text { Johnson, Robinson ve Philpot, 2020; Karvonen, 2020) }\end{array}$ \\
2 & Dayanıklıık & (Tanner vd., 2009; Arafah ve Winarso, 20I7; Tzioutziou ve Xenidis, 202I) \\
3 & Mülkiyet düzenlemesi ve dönüşüm & (Muñoz-Erickson vd., 20I6; Kumar, Singh ve Gupta, 20I9) \\
4 & Enerji verimliliği ve yenilenebilir enerji & (Arafah ve Winarso, 20।7; Parks, 20I9; Gustafsson ve Mignon, 2020) \\
5 & Elektronik yönetişim (e-yönetişim) & (Pereira vd., 20I8; Hughes vd., 20I9; Aijaz, 2020) \\
6 & Yeşil altyapı, kentsel ormanlar & (Yao vd., 20I9) \\
7 & Akıllı toplum & (Israilidis, Odusanya ve Mazhar, 20I9; Aijaz, 2020; Tzioutziou ve Xenidis, 202I) \\
8 & Su kaynakları yönetimi & (Balogun vd., 2020; Aijaz, 2020) \\
\hline
\end{tabular}


Tablo 3'te, iklim değişikliğine mekânsal uyumu desteklemek üzere çeşitlenen konu başlıklarından işbirliği-ağlar ve katılım mekanizmasının sıkça vurgulandığı görülmektedir. Ayrıca, akıllı yönetişim ile dayanıklı kentler yaratılabileceğine değinilmekte ve enerji verimliliği, yeşil altyapı ve su yönetimi gibi iklim değişikliğine uyumda öne çıkan konuların akıllı yönetişim çerçevesinde de tartışıldığına vurgu yapılmaktadır.

Ancak, literatürde akıllı yönetişime ilişkin bazı eleştirilere de yer verilmektedir. Kumar, Singh ve Gupta'ya göre, özellikle gelişmekte olan ülkelerde dijital altyapı eksikliğinden dolayı yerel halkın katılımının sağlanmadığına dikkat çekilmektedir (2019). Teknoloji kullanımın temel alan politikalar ve gündelik yaşam arasındaki farklılardan dolayı teknolojiye uyum sağlamada zorluklar yaşanabileceğine değinilmektedir (Lammers ve Hoppe, 2018; Broto ve Westman, 2019; Gustafsson ve Mignon, 2020). Ayrıca, çok aktörlü katılımın sağlanamaması durumunda iklim değişikliğine mekânsal uyum bağlamında akıllı yönetişimden bahsedilemeyeceğinin altı çizilmektedir. Benzer şekilde, yalnızca teknoloji altyapısının kurulması ve teknolojik yatırımların akıllı yönetişimin oluşturulmasında yeterli olmayacağına, aynı zamanda teknolojiyi kamu yararı için kullanacak ve denetimini sağlayacak yönetimlerin ve halkın olması gerektiğine vurgu yapılmaktadır (Meijer ve Bolvar, 2016). Özellikle yerel düzeyde teknolojiye erişim maliyetlerinin yüksek olması sebebiyle yerel halk tarafından karşılanabilir olmadığı ve akıllı yönetişim kapsamında önem taşıyan e-katılım ortamının oluşturulamadığının altı çizilmekte$\operatorname{dir}$ (Aijaz, 2020). Öte yandan, literatürde akıllı yönetişimin iklim değişikliğine mekânsal uyumda nasıl bir rol üstlenmesi gerektiğine dair yeterince çalışmanın olmayışına da değinilmektedir (Muñoz-Erickson vd., 2016; Broto ve Westman, 2019).

Yukarıda verilen bilgilere ek olarak, konuyu detaylıca ele almak amacıyla çalışmalar; akıllı yönetişimin ilkeleri, uygulama düzeyi, katılım mekanizması, teknolojinin kapsamı ve iklim değişikliğine mekânsal uyumda nasıl bir rol üstlendiği başlıklarında incelenmiştir (Tablo 4).

Tablo 4'teki yayınlarda içerik analizi yapıldığında akıllı yönetişimde öne çıkan konular arasında akıllı yönetişimi tanımlayıcı ilkeler, uygulama düzeyleri, katılım mekanizmasının içeriği ve aktörler, teknolojik araçların tarifi ve akıllı yönetişimin rolünün ne olduğu öne çıkmaktadır. Buna göre;

- Akılı yönetişim ilkelerinde iklim değişikliğine mekânsal uyumu sağlayacak arazi kullanım kararlarının düzenlenmesi, yere özgü öncelikli alanlarda politika geliştirilmesi, yerel halkın ve kırılgan grubun sürece dahil edilmesi, anlık veri paylaşımı ile katılımın sağlanması, teknolojik hizmetlerin herkes tarafından erişilebilir olması, halka bilinçlendirme çalışmalarının yapılması, uzmanlaşmış işgücünün artırılması, veriye dayalı politika üretilmesi, halk katılımını sağlamak üzere e-uygulamaların geliştirilmesi, yeşil ve açık alanlarda iyileştirmeler yapılması, akıllı sayaçların kullanılması, konut alanlarında enerji etkin tasarımlara teşvik edilmesi, kontrol panelleri kurulması, verilerin tek bir yerde toplanmasının sağlanması, izleme ve denetleme mekanizmasının kurulması, yenilenebilir enerji kaynaklarının kullanılmasına teşvik edilmesi, akıllı telefon kullanımının artırılması ve biyoçeşitlilik alanlarının/ hassas alanların tespitinin yapılması gibi ilkeler öne çıkmaktadır. Literatürden derlenen bu ilkeler çalışma kapsamında, arazi kullanımına dair ilkeler, yerel halkın bilinçlendirilmesine dair ilkeler, veri ve teknoloji kullanımına ilişkin ilkeler, yeşil altyapı, su yönetimi ve enerji verimliliğinin sağlanmasına dair ilkeler ve kentsel sistemlere (ulaşım, konut, eğitim gibi) dair ilkeler olarak 5 kategoride toplanabilir.

- Tüm yayınlarda uygulama düzeyinde yerel düzey sıklıkla vurgulanmıştır. İklim değişikliğine mekânsal uyum politikaları yere özgü olduğundan akıllı yönetişimde ulusal düzeyden çok yerel düzeyin önemli olduğuna dikkat çekilmektedir.

- Katılım mekanizması içerisinde aktörlerin çeşitlenmesi gerektiğine vurgu yapılarak çok aktörlü katılım sağlanmasının altı çizilmiştir. Kamu-özel-STK işbirlikleri yerel yönetimlerin ve yerel halkın katılımı önemsenmektedir.

- Teknolojik araçlarda aktif BiT kullanımı, Büyük Verinin işlenmesi, uzaktan algılama, yapay zekâ, sosyal medya uygulamaları ve GIS kullanımı ile e-yönetişimin sağlanması öne çıkmaktadır.

- Akıllı yönetişimin rolü ise iklim değişikliğine mekânsal uyumda uygulamaları hızlandırıcı, yönlendirici, kolaylaştırıcı ve denetleyici bir rol üstlenmekte ve iklim değişikliği etkilerine karşı dayanıklı şehir oluşumuna katkı sağlayıcı olarak tanımlanmıştır.

Konuya ilişkin literatürde, akıllı yönetişim iklim değişikliğine mekânsal uyum için etkin bir araç olarak değerlendirilmektedir. Mekânsal planlamanın akıllı yönetişim ile araçsallaştırılmasında önem taşıyan bileşenler akıllı yönetişimde mekânsal uyum ilkeleri, yerel düzey, katılım ve teknoloji olarak tarif edilmektedir. Bu bileşenler doğrultusunda Türkiye'deki uygulamaların mevcut durum değerlendirmesi benzer yaklaşımla ele alınacaktır.

\section{I. Türkiye'de İklim Değişikliğine Uyumda Mekânsal Planlama ve Akıllı Yönetişim}

Türkiye'nin önümüzdeki yıllarda doğal iklim değişikliği, sanayileşme ve kentleşmeye bağı kaynak tüketiminde artış ve iklim değişikliği etkilerine karşı kırılgan olması beklenmektedir (Kıvılcım, 20I3). Bu bağlamda, iklim değişikliğine uyum kapsamında Türkiye'de üst ölçekte politika ve stratejiler üretilmektedir (Şahin, 20l4). Bir taraftan ulusal düzeyde kamu kuruluşları yanı sıra diğer aktörler ile kurumsal yapılanmanın güçlü sayıldığı belirtilirken; bu dokümanların yerel düzeydeki uygulamalara yeterince entegre olmadığı belirtilmektedir. 
Tablo 4. İklim değişikliğine uyum ve mekânsal planlama bağlamında akıllı yönetişim

\begin{tabular}{|c|c|c|c|c|c|}
\hline \multicolumn{6}{|c|}{ Akıllı yönetişimde öne çıkan konular } \\
\hline Kaynaklar & İlkeleri & $\begin{array}{l}\text { Uygulama } \\
\text { düzeyi }\end{array}$ & $\begin{array}{l}\text { Katılım } \\
\text { mekanizması }\end{array}$ & Teknoloji & Rolü \\
\hline $\begin{array}{l}\text { Corfee- } \\
\text { Morlot vd., } \\
2009\end{array}$ & $\begin{array}{l}\text { Kentin ihtiyacına göre öncelikli alanlarda } \\
\text { politikalar geliştirilmesi, arazi kullanım } \\
\text { planlamasıyla taşkın kontrolünün } \\
\text { sağlanması, su temini için önemli alanların } \\
\text { politikalar geliştirilmesi, arazi kullanım } \\
\text { tespiti, halkı bilinçlendirme } \\
\text { çalışmalarının yapılması }\end{array}$ & Ulusal ve yerel & $\begin{array}{l}\text { Yerel düzeyden ulusal } \\
\text { düzeye kadar çeşitli } \\
\text { aktörler (kamu-özel } \\
\text { ortaklıkları) } \\
\text { tanımlanması }\end{array}$ & Biт kullanımı & $\begin{array}{l}\text { Uygulamayı } \\
\text { hızlandırıcı ve } \\
\text { kolaylaştırıcı }\end{array}$ \\
\hline $\begin{array}{l}\text { Tanner vd., } \\
2009\end{array}$ & $\begin{array}{l}\text { Fiziksel altyapı yatırımlarının } \\
\text { tamamlanması, alt gelir grubunun karar } \\
\text { alma süreçlerine katılması ve güvenli } \\
\text { barınma haklarının geliştirilmesi, su ve } \\
\text { sanitasyon gibi kritik hizmetlere erişimin } \\
\text { artırılması, plansız gelişim alanları } \\
\text { oluşmasının önlenmesi }\end{array}$ & Yerel & $\begin{array}{l}\text { Çok aktörlü } \\
\text { katılım sağlanması }\end{array}$ & BіT kullanımı & $\begin{array}{l}\text { Uygulamayı } \\
\text { hızlandırıcı, } \\
\text { kolaylaştırıcı ve } \\
\text { denetleyici }\end{array}$ \\
\hline $\begin{array}{l}\text { Muñoz- } \\
\text { Erickson vd., } \\
2016\end{array}$ & $\begin{array}{l}\text { Anlık veri paylaşımının yerel halka } \\
\text { açılması, güvenilir veri üretiminin } \\
\text { sağlanması, arazi kullanım kararlarında } \\
\text { mülkiyet düzenlemesi yapııması (çok } \\
\text { parçalı mülkiyetin uzlaşma yolu ile } \\
\text { toplulaştırılması) }\end{array}$ & Yerel & $\begin{array}{l}\text { Çok aktörlü katılım, } \\
\text { kamu-özel ortaklıkları } \\
\text { ve işbirlikleri } \\
\text { tanımlanması }\end{array}$ & $\begin{array}{l}\text { Büyük veri } \\
\text { kullanımı, } \\
\text { sosyal medya, } \\
\text { GIS kullanımı }\end{array}$ & $\begin{array}{l}\text { Uygulamayı } \\
\text { hızlandırıcı ve } \\
\text { denetleyici }\end{array}$ \\
\hline $\begin{array}{l}\text { Arafah ve } \\
\text { Winarso, } \\
2017\end{array}$ & $\begin{array}{l}\text { Sürdürülebilirliğin sağlanması için } \\
\text { uluslararası kararların takip edilmesi, } \\
\text { halkı bilinçlendirme çalışmaları ile akıllı } \\
\text { toplum oluşturulması, halkın BiT } \\
\text { hizmetlerine erişiminin sağlanması }\end{array}$ & Yerel & $\begin{array}{l}\text { Yerel yönetimler } \\
\text { temelinde çok aktörlü } \\
\text { katılım mekanizmasının } \\
\text { sağlanması }\end{array}$ & BїT kullanımı & $\begin{array}{l}\text { Dayanıklı şehir } \\
\text { oluşturmaya katkı } \\
\text { sağlayıcı }\end{array}$ \\
\hline $\begin{array}{l}\text { Pereira vd., } \\
2018\end{array}$ & $\begin{array}{l}\text { Veriye dayalı politika üretiminin } \\
\text { sağlanması, yerel halkın yaşam biçimine } \\
\text { uygun mekansal uyum politikalarının } \\
\text { üretilmesi, e-uygulamaların geliştirilmesi }\end{array}$ & Yerel & $\begin{array}{l}\text { Yerel halk temelinde } \\
\text { çok aktörlü katılım } \\
\text { mekanizması } \\
\text { sağlanması }\end{array}$ & $\begin{array}{l}\text { E-katılım/ } \\
\text { yönetişim }\end{array}$ & $\begin{array}{l}\text { Uygulamayı } \\
\text { kolaylaştırıcı ve } \\
\text { denetleyici }\end{array}$ \\
\hline $\begin{array}{l}\text { Yao vd., } \\
2019\end{array}$ & $\begin{array}{l}\text { Sosyal sermayeyi harekete geçirmek } \\
\text { üzere özellikle yerel ölçekte belediye } \\
\text { sistemlerinin yeniden düzenlenmesi, } \\
\text { yeşil altyapının oluşturulması için mevcut } \\
\text { yeşil alanlarda iyileştirilmelerin yapılması, } \\
\text { yeni yeşil alanlar için potansiyel alanların } \\
\text { halk katılımı ile geliştirilmesi }\end{array}$ & Ulusal ve yerel & $\begin{array}{l}\text { Çok aktörlü katılım } \\
\text { mekanizması (Yeşil } \\
\text { dernekler, yerel ve } \\
\text { ulusal yönetimler) } \\
\text { sağlanması }\end{array}$ & BїT kullanımı & $\begin{array}{l}\text { Uygulamaları } \\
\text { hızlandırıcı }\end{array}$ \\
\hline Parks, 2019 & $\begin{array}{l}\text { Enerji verimliliğini sağlamak üzere akıllı } \\
\text { sayaçların yerleştirilmesi, kullanılan enerji } \\
\text { miktarına göre yerel halkın } \\
\text { bilinçlendirilmesi, kullanım süresine göre } \\
\text { fiyatlandırmalarda değişiklikler yapılması, } \\
\text { yerel halk ile birlikte üretme süreçlerinin } \\
\text { oluşturulması }\end{array}$ & Yerel & $\begin{array}{l}\text { Yerel halk temelinde } \\
\text { çok aktörlü katılım } \\
\text { sağlanması }\end{array}$ & $\begin{array}{l}\text { Büyük veri } \\
\text { kullanımı, Biт } \\
\text { kullanımı, } \\
\text { sosyal medya }\end{array}$ & $\begin{array}{l}\text { Uygulamayı } \\
\text { kolaylaştırıcı ve } \\
\text { hızlandırıcı }\end{array}$ \\
\hline
\end{tabular}


Tablo 4 (devamı). İklim değişikliğine uyum ve mekânsal planlama bağlamında akıllı yönetişim

\begin{tabular}{|c|c|c|c|c|c|}
\hline \multicolumn{6}{|c|}{ Akıllı yönetişimde öne çıkan konular } \\
\hline Kaynaklar & İlkeleri & $\begin{array}{l}\text { Uygulama } \\
\text { düzeyi }\end{array}$ & $\begin{array}{l}\text { Katılım } \\
\text { mekanizması }\end{array}$ & Teknoloji & Rolü \\
\hline $\begin{array}{l}\text { Hughes vd., } \\
2019\end{array}$ & $\begin{array}{l}\text { Yerel halkı bir araya getirmek için } \\
\text { katılımcı ortamların oluşturulması, } \\
\text { uzmanlaşmış işgücünü artırmaya yönelik } \\
\text { çalışmalar yapılması, toplum merkezli bir } \\
\text { sistem ile iklim değişikliği etkilerine karşı } \\
\text { bilinçlendirme yapılması, şehir kontrol } \\
\text { panelleri kurularak idari verilere ek } \\
\text { olarak konuya ilişkin çeşitli veri türlerinin } \\
\text { tek bir yerde görüntülemesine olanak } \\
\text { sağlanması }\end{array}$ & Yerel & $\begin{array}{l}\text { Çok aktörlü katılım } \\
\text { sağlanması }\end{array}$ & $\begin{array}{l}\text { Büyük veri } \\
\text { kullanımı, } \\
\text { e-katılım/ } \\
\text { yönetişim }\end{array}$ & $\begin{array}{l}\text { Uygulamayı } \\
\text { kolaylaştırıcı }\end{array}$ \\
\hline $\begin{array}{l}\text { Kumar, Singh } \\
\text { ve Gupta, } \\
2019\end{array}$ & $\begin{array}{l}\text { Uzmanlar yardımı ile yerel yönetimlerde } \\
\text { mevcut yönetişim sisteminin dijitalleşmesi, } \\
\text { kırılgan alanların tespiti, BiT ile izleme- } \\
\text { denetleme mekanizmasının kurulması, } \\
\text { uluslararası örneklerin incelenmesi ve } \\
\text { yerel halka tanıtılması }\end{array}$ & Yerel & $\begin{array}{l}\text { Yerel yönetimler ve } \\
\text { yerel halk temelinde } \\
\text { çok aktörlü katılımın } \\
\text { sağlanması }\end{array}$ & BIT kullanımı & $\begin{array}{l}\text { Uygulamayı } \\
\text { kolaylaştırıcı }\end{array}$ \\
\hline $\begin{array}{l}\text { Israilidis, } \\
\text { Odusanya ve } \\
\text { Mazhar, } 2019\end{array}$ & $\begin{array}{l}\text { İklim projeksiyonlarına göre hassas } \\
\text { alanların tespiti, kentlerde yeni gelişme } \\
\text { alanlarının KIA etkisi yaratmayacak ve } \\
\text { rüzgar koridorlarını etkilemeyecek } \\
\text { şekilde kurgulanması, karbon salımını } \\
\text { azaltma stratejilerinin yerel halk ile } \\
\text { belirlenmesi }\end{array}$ & Yerel & $\begin{array}{l}\text { Yerel yönetimler ve } \\
\text { yerel halk temelinde } \\
\text { çok aktörlü katılımın } \\
\text { sağlanması }\end{array}$ & Biт kullanımı & $\begin{array}{l}\text { Uygulamayı } \\
\text { hızlandırıcı }\end{array}$ \\
\hline $\begin{array}{l}\text { Balogun vd., } \\
2020\end{array}$ & $\begin{array}{l}\text { İklim değişikliği etkilerine karşı büyük } \\
\text { verinin analiz edilmesi, öncelikli konulara } \\
\text { göre yönetişimin şekillenebilmesi (su } \\
\text { kıtlığına karşı su yönetim politikalarına } \\
\text { ağırlık verilmesi gibi), katılımı } \\
\text { kolaylaştırmak üzere telefonlarda akıllı } \\
\text { uygulamaların kullanılmasına teşvik } \\
\text { edilmesi }\end{array}$ & Yerel & $\begin{array}{l}\text { Çok aktörlü katılım } \\
\text { sağlanması }\end{array}$ & $\begin{array}{l}\text { Büyük veri } \\
\text { kullanımı }\end{array}$ & $\begin{array}{l}\text { Uygulamayı } \\
\text { kolaylaştırıcı }\end{array}$ \\
\hline $\begin{array}{l}\text { Gustafsson } \\
\text { ve Mignon, } \\
2020\end{array}$ & $\begin{array}{l}\text { Yenilenebilir enerji kaynaklarının } \\
\text { kullanılmasına teşvik edilmesi, topluluk } \\
\text { girişimleri ile üretilen projelerin } \\
\text { desteklenmesi (rüzgar enerjisi projesi), } \\
\text { yerel düzeyde üretilecek planlarda çok } \\
\text { aktörlü katılımın sağlanması }\end{array}$ & Yerel & $\begin{array}{l}\text { Yerel yönetimler başta } \\
\text { olmak üzere ulusal ve } \\
\text { uluslararası aktörler } \\
\text { tanımlanması }\end{array}$ & $\begin{array}{l}\text { Büyük veri } \\
\text { kullanımı, } \\
\text { BiтT kullanımı, } \\
\text { sosyal medya }\end{array}$ & $\begin{array}{l}\text { Uygulamayı } \\
\text { kolaylaştırıcı ve } \\
\text { hızlandırıcı }\end{array}$ \\
\hline Aijaz, 2020 & $\begin{array}{l}\text { Yerel halkın kesintisiz katılımı için ücretsiz } \\
\text { wifı hizmet noktalarının oluşturulması, } \\
\text { akıllı telefonların kullanımının artırılması } \\
\text { için telefon fiyatlarının makul düzeyde } \\
\text { tutulması, çevrimiçi hizmetlere olan } \\
\text { bağlıı̆ın geliştirilmesi için bilinçlendirme } \\
\text { çalışmalarının yapılması }\end{array}$ & Yerel & $\begin{array}{l}\text { Kamu-özel işbirlikleri } \\
\text { başta olmak üzere çok } \\
\text { aktörlü katılım } \\
\text { sağlanması }\end{array}$ & $\begin{array}{l}\text { BiT kullanımı, } \\
\text { sosyal medya, } \\
\text { e-katılım/ } \\
\text { yönetişim }\end{array}$ & $\begin{array}{l}\text { Uygulamayı } \\
\text { hızlandırıcı }\end{array}$ \\
\hline
\end{tabular}


Tablo 4 (devamı). İklim değişikliğine uyum ve mekânsal planlama bağlamında akıllı yönetişim

\begin{tabular}{|c|c|c|c|c|c|}
\hline \multicolumn{6}{|c|}{ Akıllı yönetişimde öne çıkan konular } \\
\hline Kaynaklar & İlkeleri & $\begin{array}{l}\text { Uygulama } \\
\text { düzeyi }\end{array}$ & $\begin{array}{l}\text { Katılım } \\
\text { mekanizması }\end{array}$ & Teknoloji & Rolü \\
\hline $\begin{array}{l}\text { Castán } \\
\text { Broto ve } \\
\text { Westman, } \\
2020\end{array}$ & $\begin{array}{l}\text { Değişen iklim koşullarına uyum sağlamak } \\
\text { üzere esnek, kentsel sistemlere (ulaşım, } \\
\text { hizmet, eğitim, sağılı gibi) konunun } \\
\text { entegre edilmesini sağlayacak teknolojik } \\
\text { altyapının kurulması, öncelikli olarak } \\
\text { kentlerde fiziksel altyapının (atık-içme } \\
\text { suyu-kanalizasyon, arıtma tesisleri, } \\
\text { yol gibi) tamamlanması }\end{array}$ & Ulusal ve yerel & $\begin{array}{l}\text { Çok aktörlü katılım } \\
\text { sağlanması ve } \\
\text { işbirlikleri tanımlanması }\end{array}$ & BíT kullanımı & $\begin{array}{l}\text { Uygulamayı } \\
\text { hızlandırıcı ve } \\
\text { yönlendirici }\end{array}$ \\
\hline $\begin{array}{l}\text { Karvonen, } \\
2020\end{array}$ & $\begin{array}{l}\text { Büyük verilerin işlenmesi ile sosyal ağ } \\
\text { analizlerinin yapılması ve kentsel } \\
\text { farkındalığın artırılması }\end{array}$ & Yerel & $\begin{array}{l}\text { Kamu-özel işbirlikleri } \\
\text { ile çok aktörlü katılım } \\
\text { sağlanması }\end{array}$ & $\begin{array}{l}\text { Büyük veri } \\
\text { kullanımı, } \\
\text { sosyal medya, } \\
\text { uzaktan algılama, } \\
\text { yapay zeka }\end{array}$ & $\begin{array}{l}\text { Uygulamayı } \\
\text { hızlandırıcı }\end{array}$ \\
\hline $\begin{array}{l}\text { Johnson, } \\
\text { Robinson ve } \\
\text { Philpot, } 2020\end{array}$ & $\begin{array}{l}\text { Kararların yerel halk tarafından } \\
\text { benimsenmesi için süreç boyunca } \\
\text { katılımın yüksek tutulması, öncelikli } \\
\text { müdahale alanlarına göre yerel düzeyde } \\
\text { örgütlenme sağlanarak bilinçlendirme } \\
\text { çalışmaları yapııması }\end{array}$ & Yerel & $\begin{array}{l}\text { Yerel halk temelinde } \\
\text { çok aktörlü katılım } \\
\text { sağlanması }\end{array}$ & BiT kullanımı & $\begin{array}{l}\text { Uygulamayı } \\
\text { kolaylaştırıcı ve } \\
\text { denetleyici }\end{array}$ \\
\hline $\begin{array}{l}\text { Tzioutziou } \\
\text { ve Xenidis, } \\
2021\end{array}$ & $\begin{array}{l}\text { Karbon bağımlı sektörlerin yenilenebilir } \\
\text { enerji kullanımına teşvik edilmesi, } \\
\text { hassas alanların tespiti ve korunması }\end{array}$ & Yerel & $\begin{array}{l}\text { Yerel yönetimler } \\
\text { temelinde çok boyutlu } \\
\text { katılım sağlanması }\end{array}$ & $\begin{array}{l}\text { Büyük veri ve } \\
\text { BiT kullanımı }\end{array}$ & $\begin{array}{l}\text { Dayanıklı şehir } \\
\text { oluşturmaya katkı } \\
\text { sağlayıcı }\end{array}$ \\
\hline
\end{tabular}

Dolayısıyla, Türkiye'de özellikle son yıllarda iklim değişikliğine uyum kapsamında mekânsal planlamanın bir araç olarak kullanılması için yerel ölçekte politikalar geliştirilmesi gerekliliğine sıklıkla vurgu yapılmaktadır (Köse, 2018; Gedikli ve Balaban, 2018). Ancak, kentlerde iklim değişikliğine uyum planları, kentsel gelişim planları ile eş zamanlı üretilmemesi önemli bir sorun olarak görülmektedir. Kentler sürekli değişen ve gelişen bir yapıya sahip olsa da iklim değişikliği etkilerinin mekânsal planlara işlenmemesinin mekânsal uyum sürecini zorlaştırdığına değinilmektedir (Balaban ve Balaban, 20I5). Öte yandan, yerel düzeyde üretilen iklim değişikliğine uyum planları genellikle sektörel/tematik içerikte olduğundan mekânsal planla ilişkilendirilmesinde zorluklar yaşanmaktadır. Genellikle, bir kentte iklim değişikliğine uyum için üretilen planda karbon azaltımıyla hava kalitesi ve çevresel göstergelerin iyileştirilmesinin öne çıkmakta ancak mekânda nasıl bir uygulama alanı oluşturacağına değinilmemektedir. Halbuki, yerel ölçekte üretilecek planların yerin koşulları (kentteki hassas alanlar, sulak alanlar, biyoçeşitlilik için önemli alanlar, tarihi ve kültürel değerler gibi) göz önüne alınarak geliştirilmesi gerektiği savunulmaktadır (Kpienbaareh vd., 2020; Bütün Bayındır, 2020).
Buna göre, çalışma kapsamında ilk olarak Türkiye'de konuya ilişkin uygulamaları içeren planların yerel düzeydeki durumu ortaya konacaktır (Şekil 4).

Şekil 4'te görüldüğü üzere iklim değişikliğine yönelik faaliyetlerin çoğu 2015 yılından sonra yapılmıştır. İklim değişikliğinin etkilerini azaltmak ve uyum sağlamak üzere 2015 yılında imzalanan Paris Anlaşmasının, uygulamaları hızlandırdığı ve iklim değişikliğine karşı yerel düzeyde farkındalık geliştirmeye katkı sağladığı söylenebilir. Diğer taraftan, Türkiye'de yerel düzeyde yapılan plan ve raporların büyük bir kısmının bütünleşik olduğu görülmektedir. Örneğin, Yerel İklim Değişikliği Eylem Planına sahip çoğu kentte sera gazı envanteri de çıkarılmıştır. Ancak, Enerji Eylem Planları ile hala tam entegrasyon sağlanamadığı da görülmektedir. Öte yandan, birçok Büyükşehir Belediyesinde iklim değişikliğine uyum kapsamında henüz plan/ rapor üretilmediğine de dikkat çekilmektedir.

Yerel düzeyde Türkiye'de iklim değişikliğine uyum kapsamında öne çıkan Yerel İklim Değişikliği Eylem Planı, Sera Gazı Envanteri ve Enerji Eylem Planı içerisinden mekânsal uyum politikalarının değerlendirilmesi bağlamında Yerel İklim Değişikliği Eylem Planı 


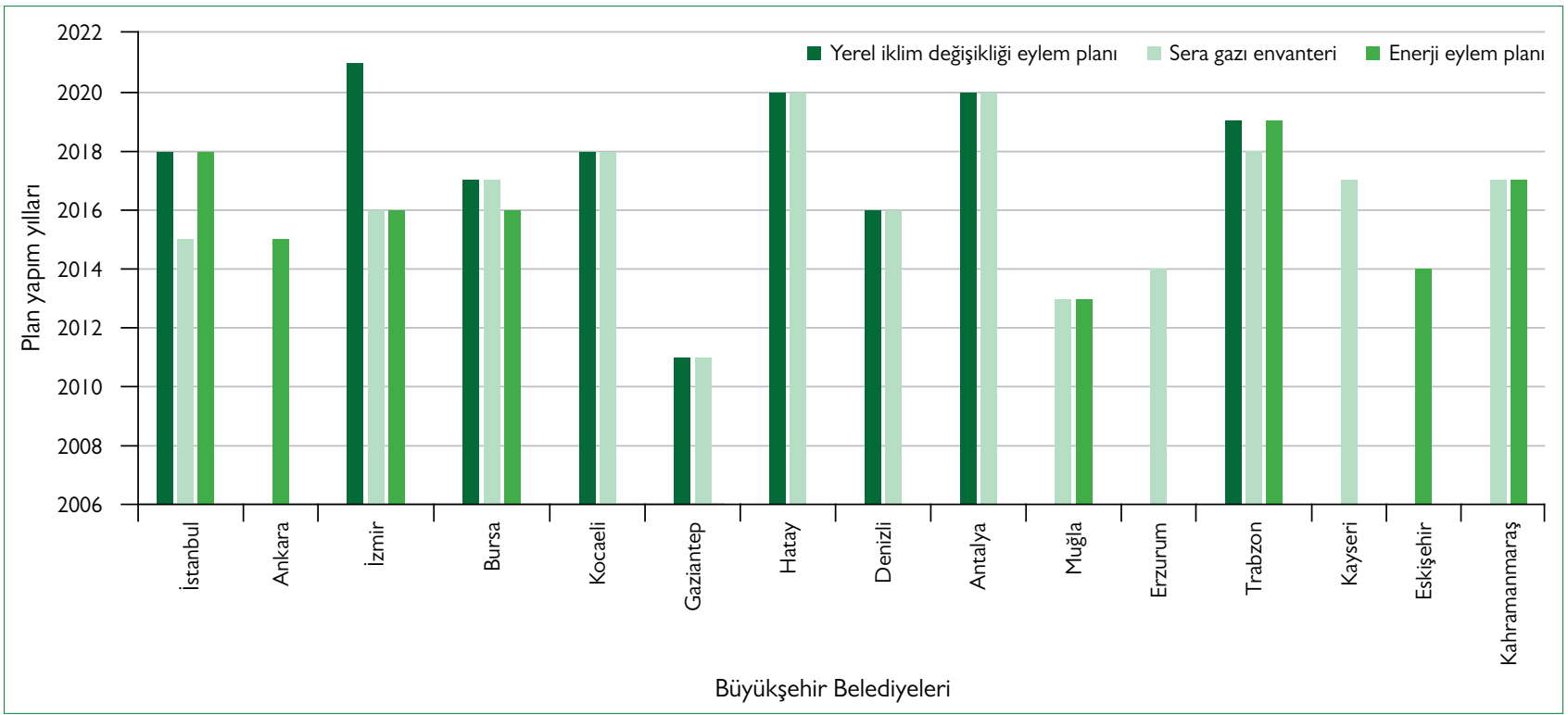

Şekil 4. Türkiye’de yerel yönetimlerin iklim değişikliğine yönelik faaliyeti.

Tablo 5. Türkiye'de Yerel İklim Eylem Planına sahip kentler üzerinden akıllı yönetişimdeki mevcut durum

Akıllı yönetişim bileşenleri

Büyükşehir Belediyeleri

İstanbul İzmir Bursa Denizli Antalya Gaziantep Kocaeli Trabzon Hatay

Mekansal uyum ilkeleri

Arazi kullanım düzenlemeleri

Veri ve teknoloji kullanımı

Kentsel sistemlerin düzenlenmesi

Yerel halkın bilinçlendirilmesi

Su yönetimi ve enerji verimliliğinin sağlanması Katılım/aktörler

Kamu kurum kuruluşları

Özel sektör

STK

Diğer (üniversite, meslek odaları gibi)

Teknoloji kullanımı

E-uygulamalar

BiT kullanımı

$\begin{array}{rlllllllll}+ & + & + & + & - & + & + & + & + \\ + & + & + & + & + & + & + & - & + \\ + & + & - & + & + & + & + & + & + \\ + & + & + & + & - & + & + & + & + \\ + & + & + & + & + & + & + & + & + \\ + & + & + & + & + & + & + & + & + \\ + & + & + & + & + & + & + & + & + \\ + & + & + & + & + & + & + & + & + \\ + & + & + & + & + & + & + & + & + \\ + & - & - & - & - & - & + & - & - \\ + & + & - & - & - & - & + & + & -\end{array}$

STK: Sivil Toplum Kuruluşları.

(YIDEP) önem taşımaktadır. Buna göre, YiDEP'e sahip toplam 9 kent (İstanbul, İzmir, Bursa, Kocaeli, Gaziantep, Denizli, Antalya, Trabzon ve Hatay) için akıllı yönetişim bileşenleri ile değerlendirme yapılacak ve Türkiye'deki mevcut durum ortaya koyulacaktır. Bir başka deyişle, literatürden içerik analizi yöntemi ile elde edilen IDU ve MP konularında akıllı yönetişime ilişkin; mekânsal uyum ilkeleri (arazi kullanımına dair, yerel halkın bilinçlendirilmesine dair, veri ve teknoloji kullanımına ilişkin, yeşil altyapı, su yönetimi ve enerji verimliliğinin sağlanmasına dair ve kentsel sistemlere dair), katılım/aktörler ve teknoloji kullanımı olmak üzere öne çıkan temel bileşenler; Türkiye'de YIDEP uygulamalarını değerlendirmek için kullanılacaktır (Tablo 5).

Tablo 5'te Türkiye'de 30 Büyükşehir Belediyesinden sadece 9 tanesinin sahip olduğu YIDEP'de ilgili başlıklara dair çalışmaların yapılıp (+) yapılmadığı (-) gösterilmektedir. Buna göre, su 


\begin{tabular}{|c|c|c|c|}
\hline $\begin{array}{l}\text { Literatür araştırmasında } \\
\text { kullanılan kavramlar }\end{array}$ & $\begin{array}{c}\text { Anahtar kavramlara } \\
\text { göre yayın sayısı }\end{array}$ & $\begin{array}{c}\text { Yayınlarda öne çıkan } \\
\text { kavramlar }\end{array}$ & \\
\hline (İklim değişikliğine uyum) ve (mekânsal planlama) & 102 adet doküman & & \\
\hline $\begin{array}{l}\text { (İklim değişikliğine uyum) ve (mekânsal planlama) } \\
\text { içinden (yönetişim), (teknoloji), (katılım) }\end{array}$ & 26 adet doküman & etişim & \\
\hline $\begin{array}{l}\text { (İklim değişikliğine uyum) ve (mekânsal planlama) } \\
\text { içinden (akıllı yönetişim) }\end{array}$ & 17 adet doküman & $\begin{array}{ll}\cdot \text { ilkeler } \quad \text { katılım } \\
\cdot \text { yerel düzey } & \text { - teknoloji }\end{array}$ & Türkiye \\
\hline
\end{tabular}

Şekil 5. Çalışma kapsamında literatür değerlendirmesi ve sonuçları.

yönetimi ve enerji verimliliği konuları oldukça önem taşıdığı ve akıllı yönetişimin diğer ilkelerinden arazi kullanım düzenlemeleri ve bilinçlendirme çalışmalarının da dikkate alındığı görülmektedir. Diğer taraftan, yapılan planların çok aktörlü hazırlanması yerel düzeyde çoğunlukla katılım mekanizmasının gelişmiş olduğunu göstermektedir. Ancak, akıllı yönetişimin bir diğer önemli bileşeni olan teknoloji kullanımına ilişkin BiT kullanımı ve e-uygulamaların henüz geliştirilmediği ve uygulamalarda aktif olarak kullanılamadığı görülmektedir. Yalnızca Kocaeli kentinde kentsel sistemler içerisinden ulaşımda, toplu taşımanın desteklenmesi için e-uygulama modelinin geliştirilmesine değinilmiştir. Dolayısıyla, iklim değişikliğine mekânsal uyumun akıllı yönetişim ile sağlanması için teknoloji kullanımında eksiklikler tespit edilmekte ve çalışmaların artırılması gerekmektedir.

Bu bölümde, iklim değişikliğine mekânsal uyumda akıllı yönetişim bileşenleri ile Türkiye'de bir değerlendirme yapılmıştır. İklim değişikliğine mekânsal uyumda önem taşıyan YiDEP uygulamaları, literatürden çıkarımlar yapılarak elde edilen akıllı yönetişim bileşenleri üzerinden irdelenmiştir. Sonuçta, Türkiye'de yerel düzeyde üretilen çalışmaların sayıca az olduğu (30 büyükşehir içerisinden sadece 9 tanesi) ve teknoloji kullanımı ile BiT ve e-uygulamaların gelişmediği tespit edilmiştir.

\section{Sonuç}

Çalışmada, iklim değişikliğine uyumda mekânsal planlamanın yeri ve önemi tartışılmakta ve mekânsal planlamanın etkin bir araç olarak kullanılmasını sağlayacak akıllı yönetişime vurgu yapılmaktadır. Akıllı yönetişim sayesinde roller ve sorumlulukların tanımlandığı çok katmanlı katılımcı süreçler, yerel ölçekte uygulanabilir mekânsal kararlar (planlar ve projeler) ile dayanıklılı̆ın sağlandığı iklim değişikliğine mekânsal uyum politikaları geliştirilmesinin mümkün olabileceği ortaya koyulmaktadır.

Çalışma kapsamında içerik analizi yöntemi ile irdelenen literatürde ilk aşamada, konu bağlamında yönetişim, katılım ve teknoloji gibi öne çıkan kavramlar tespit edilmiştir. İkinci aşamada da bu kavramlara ek olarak akıllı yönetişim irdelenmiştir (Şekil 5). Ardından, çalışma kapsamı doğrultusunda Türkiye'de mevcut durum değerlendirmesi yapılmıştır.
Türkiye'de yapılan değerlendirmede akıllı yönetişim bileşenlerinden biri olan mekânsal uyum ilkelerinin dikkate alındığı görülmektedir. Ayrıca, mekânsal uyumda önem taşıyan YIDEP'te aktörler/paydaşların etkin rol alması, katılım mekanizmasını desteklemektedir. Ancak, teknoloji bileşeni altında yer alan BiT kullanımı ve e-uygulamalara çoğu kentte yer verilmediğinden teknoloji kullanımına ilişkin mekânsal uyum politikalarının yeterince gelişmediği görülmektedir. Bunun sebebi olarak, teknolojik altyapının sağlanmamış olması ve konuya ilişkin uzmanlaşmış işgücü gösterilebilir. Öte yandan, çoğu Büyükşehir Belediyesi tarafından YIDEP'in tamamlanmamış olması akıllı yönetişim bileşenlerinden yerel düzeydeki uygulamalarda da Türkiye'de eksiklikler olduğu göstermektedir. Hem teknoloji alanında hem de yerel düzeyde iklim değişikliğine mekânsal uyum için önem taşıyan akıllı yönetişimin ülkemizdeki mevcut durumu ortaya koyulmuş ve gelişmesi gerektiği sonucu çıkarılmıştır.

İleriki çalışmalarda, iklim değişikliğine uyumun son derece önem taşıdığı kentlerde akıllı yönetişimin mekânsal planlamada öncelikle hangi alanda kullanılması gerektiği pilot kentler üzerinden irdelenebilir. Örneğin, seçilecek bir/birden fazla kent için "iklim değişikliğine uyum bağlamında enerji etkinliğinin sağlanması üzerine mekânsal planlama yaklaşımı” sorusu ile başlayarak akıllı yönetişimde doğrudan enerji etkinliği üzerine katılımcıların (aktörler/paydaşlar) tanımlanması, yerel düzeydeki mevzuat ve konuya bakış açısının öğrenilmesi çalışılabilecek konular arasındadır. Gelişen teknolojiler ile uygulanabilir akıllı yönetişimin, politika üretmede kolaylık sağlaması ve sistematik yönetimi hızlandırması sebebiyle kentlerdeki sorunlar için çözüm aracı olması umut edilmektedir. 


\section{KAYNAKLAR}

Ahammad, R. (2011). Constraints of pro-poor climate change adaptation in Chittagong city. Environment and Urbanization, 23(2), 503-515.

Aijaz, R. (2020). The Smart Cities Mission in Delhi, 2015-2019: An Evaluation (Vol. 98).

Anguelovski, I., Carmin, J. (2011). Something barrowed everythinh new: Innovation and institutionalization in urban climate governance. Current Opinion in Environmental Sustainability, 3, 169-175.

Arafah, Y., Winarso, H. (2017). Redefining smart city concept with resilience approach. In IOP Conference Series: Earth and Environmental Science (Vol. 70, No. 1), IOP Publishing.

Aşıc1, A. A., Şahin, Ü. (Ed.) (2017). Yeşil ekonomi. Tohum Yayıncılık Turizm Reklam ve Sağlık Hizmetleri.

Balaban, O., Balaban, M. Ş. (2015). Adaptation to climate change: Barriers in the Turkish local context. TEMA Journal of Land Use, Mobility and Environment, 7-22.

Birkmann, J., Garschagen, M., Kraas, F., Quang, N. (2010). Adaptive urban governance: New challenges for the second generation of urban adaptation strategies to climate change. Sustainability Science, 5(2), 185-206.

Bolivar, M. P. (2015). Transforming city governments for successful smart cities.

Balogun, A. L., Marks, D., Sharma, R., Shekhar, H., Balmes, C., Maheng, D., Salehi, P. (2020). Assessing the potentials of digitalization as a tool for climate change adaptation and sustainable development in urban centres. Sustainable Cities and Society, 53.

Bulkeley, H. (2010). Cities and the governing of climate change. Annual Review of Environment and Resources, 35(1), 229-253.

Bütün Bayındır, G. D. (2020). How do transnational municipal networks affect climate policymaking? A qualitative study in Turkey. Journal of Urban Affairs, 1-19.

Calthorpe, P. (2010). Urbanism in the age of climate change. Island Press.

Caragliu, A., Del Bo, C., Nijkamp, P. (2011). Smart cities in Europe. Journal of Urban Technology, 18(2), 65-82.

Cardullo, P., Kitchin, R. (2019). Smart urbanism and smart citizenship: The neoliberal logic of 'citizen-focused'smart cities in Europe. Environment and Planning C: Politics and Space, 37(5), 813-830.

Carter, J. G., Cavan, G., Connelly, A., Guy, S., Handley, J., Kazmierczak, A. (2015). Climate change and the city: Building capacity for urban adaptation. Progress in planning, 95, 1- 66.

Castán Broto, V., Westman, L. K. (2020). Ten years after Copenhagen: Reimagining climate change governance in urban areas. Wiley Interdisciplinary Reviews: Climate Change, 11(4), 1-22.

Chan, F. K. S., Griffiths, J. A., Higgitt, D., Xu, S., Zhu, F., Tang, Y. T. \& Thorne, C. R. (2018). "Sponge City" in China-A breakthrough of planning and flood risk management in the urban context. Land use policy, 76, $772-778$

Clift, S. (2003). E-Democracy, E-Governance and Public Net-Work.

Corfee-Morlot, J., Kamal-Chaoui, L., Donovan, M. G., Cochran, I., Robert, A., Teasdale, P. J. (2009). Cities, climate change and multilevel governance.

Dąbrowski, M., Stead,D., He,J., Yu, F. (2021). Adaptive capacity of the Pearl River Delta cities in the face of the growing flood risk: Institutions, ideas and interests. Urban Studies, https://doi.org/10.1177/0042098020951471.

Çevre ve Şehircilik Bakanlığı (ÇŞB). (2011). Türkiye İklim Değișikliği Eylem Planı, https://webdosya.csb.gov.tr/db/iklim/editordosya/file/eylem\%20 planlari/Iklim\%20Degisikligi\%20Eylem\%20Plani_TR.pdf

Daniere, A. G., Garschagen, M. (Ed.) (2019). Urban climate resilience in Southeast Asia.

Davoudi, S., Crawford, J., Mehmood, A. (Ed.) (2009). Planning for climate change: Strategies for mitigation and adaptation for spatial planners. Earthscan.

De Falco, S., Angelidou, M., Addie, J. P. D. (2019). From the "smart city" to the "smart metropolis"? Building resilience in the urban periphery. European Urban and Regional Studies, 26(2), 205-223.

Dyson, L. (2013). Beyond transparency: Open data and the future of civic innovation.

Eger, J. M. (2009). Smart growth, smart cities, and the crisis at the pump a worldwide phenomenon. The Journal of E-Government Policy and Regulation, 32(1), 47-53.

Leal Filho., W.Balogun, A. L., Olayide, O. E., Azeiteiro, U. M., Ayal, D. Y., Muñoz, P. D. C. \& Li, C. (2019). Assessing the impacts of climate change in cities and their adaptive capacity: Towards transformative approaches to climate change adaptation and poverty reduction in urban areas in a set of developing countries. Science of the Total Environment, 692, 1175-1190.

Florida, R. (2010). Who's your city?: How the creative economy is making where to live the most important decision of your life. Vintage Kanada.

Ford, J. D., Berrang-Ford, L. \& Paterson, J. (2011). A systematic review of observed climate change adaptation in developed nations. Climatic change, 106(2), 327-336.

Fratini, C. F., Geldof, G. D., Kluck, J., Mikkelsen, P. S. (2012). Three Points Approach (3PA) for urban flood risk management: A tool to support climate change adaptation through transdisciplinarity and multifunctionality. Urban Water Journal, 9(5), 317-331.

Fröhlich, J., Knieling, J. (2013). Conceptualising climate change governance. Climate change governance, 9-26.

Gagnon-Lebrun, F., Agrawala, S. (2007). Implementing adaptation in developed countries: An analysis of progress and trends. Climate Policy, 7(5), 392-408

Gedikli, B., Balaban, O. (2018). An evaluation of local policies and actions that address climate change in Turkish metropolitan cities. European Planning Studies, 26(3), 458-479.

Giffinger, R., Fertner, C., Kramar, H., Kalasek, R., Pichler-Milanovic, N., Meijers, E. (2007). Smart cities. Ranking of European medium-sized cities. Vienna UT: Centre of Regional Science.

Gil-Garcia, J. R., Pardo, T. A., Nam, T. (2015). What makes a city smart? Identifying core components and proposing an integrative and comprehensive conceptualization. Information Polity, 20(1), 61-87.

Gossop, C. (2011). Low carbon cities: An introduction to the special issue. Cities, 28(6), 495- 497.

Greiving, S., Fleischhauer, M. (2012). National climate change adaptation strategies of European states from a spatial planning and development perspective. European Planning Studies, 20(1), 27-48.

Gustafsson, S., Mignon, I. (2020). Municipalities as intermediaries for the design and local implementation of climate visions. European Planning Studies, 28(6), 1161-1182.

Hope, K.R. (2009). Climate change and urban development in Africa. International Journal of Environmental Studies, 66(5), 643-658.

Hughes, S., Tozer, L., Giest, S., Van Der Heijden, J., Bulkeley, H., Certoma, C. (2019). The Politics of Data-Driven Urban Climate Change Mitigation. Urban Climate Politics: Agency and Empowerment, https://doi. org/10.1017/9781108632157.007, 116-134.

Hurlimann, A. C., March, A. P. (2012). The role of spatial planning in adapting to climate change. Wiley Interdisciplinary Reviews: Climate Change, 3(5), 477-488.

Israilidis, J., Odusanya, K., Mazhar, M. U. (2019). Exploring knowledge management perspectives in smart city research: A review and future research agenda. International Journal of Information Management, 56, https:// doi.org/10.1016/j.ijinfomgt.2019.07.015.

Janis, I. (1965). The problem of validating content analysis. The content analysis reader, 358-375.

Jeong, J. S. (2018). Design of spatial PGIS-MCDA-based land assessment planning for identifying sustainable land-use adaptation priorities for climate change impacts. Agricultural Systems, 167, 61-71.

Johnson, P. A., Robinson, P. J., Philpot, S. (2020). Type, tweet, tap, and pass: 
How smart city technology is creating a transactional citizen. Government Information Quarterly, 37(1).

Karvonen, A. (2020). Urban techno-politics: Knowing, governing, and imagining the city. Science as Culture, 29(3), 417-424.

Kern, K., Bulkeley, H. (2009). Cities, Europeanization and multilevel governance: Governing climate change through transnational municipal networks. Journal of Common Market Studies, 47(2), 309-332.

Kıvılcım, İ. (2013). 2020'ye Doğru Kyoto-Tipi İklim Değişikliği Müzakeleri, AB'nin Yeterliliği ve Türkiyénin Konumu. İktisadi Kalkınma Vakfı Yayı$\mathrm{n}$, İstanbul.

Kourtit, K., Nijkamp, P., Arribas, D. (2012). Smart cities in perspective - A comparative European study by means of self-organizing maps. Innovation The European Journal of Social Science Research, 25(2), 229-246.

Köse, İ. (2018). İklim Değişikliği Müzakereleri: Türkiyénin Paris Anlaşması́nı İmza Süreci. Ege Stratejik Araştırmalar Dergisi 9 (1), 55-81.

Kpienbaareh, D., Bezner Kerr, R., Luginaah, I., Wang, J., Lupafya, E., Dakishoni, L., Shumba, L. (2020). Spatial and Ecological Farmer Knowledge and Decision-Making about Ecosystem Services and Biodiversity. Land, 9(10), 356.

Krippendorff, K. (2018). Content analysis: An introduction to its methodology. Sage publications.

Kumar, C. B. (2013). Climate change and Asian cities: So near yet so far. Urban Studies, 50(7), 1456-1468.

Kumar, T. V. (2015). E-governance for smart cities. E-governance for smart cities, 1-43.

Kumar, H., Singh, M. K., Gupta, M. P. (2019). A policy framework for city eligibility analysis: TISM and fuzzy MICMAC-weighted approach to select a city for smart city transformation in India. Land use policy, 82.

Kundzewicz, Z. W., Su, B., Wang, Y., Xia, J., Huang, J., Jiang, T. (2019). Flood risk and its reduction in China. Advances in Water Resources, 130, 37-45.

Lammers, I., Hoppe, T. (2018). Analysing the institutional setting of local renewable energy planning and implementation in the EU: A systematic literature review. Sustainability, 10(9), 3212

Lin, Y., Zhang, X., Geertman, S. (2015). Toward smart governance and social sustainability for Chinese migrant communities. Journal of Cleaner Production, 107, 389-399.

Lopes, N. V. (2017). Smart governance: A key factor for smart cities implementation. In 2017 IEEE International Conference on Smart Grid and Smart Cities (ICSGSC), 277-282.

Lorenz, S., Dessai, S., Forster, P. M., Paavola, J. (2017). Adaptation planning and the use of climate change projections in local government in England and Germany. Regional Environmental Change, 17(2), 425-435.

Macintosh, A., Foerster, A., McDonald, J. (2015). Policy design, spatial planning and climate change adaptation: A case study from Australia. Journal of environmental planning and management, 58(8), 1432-1453.

MacLeod, G. (2011). Urban politics reconsidered: Growth machine to postdemocratic city? Urban Studies, 48(12), 2629-2660.

Matthews, T., Lo, A. Y., Byrne, J. A. (2015). Reconceptualizing green infrastructure for climate change adaptation: Barriers to adoption and drivers for uptake by spatial planners. Landscape and Urban Planning, 138, 155-163.

Mees, H. L., Dijk, J., van Soest, D., Driessen, P. P., van Rijswick, M. H., Runhaar, H. (2014). A method for the deliberate and deliberative selection of policy instrument mixes for climate change adaptation. Ecology and Society, 19(2).

Meijer, A., Bolívar, M. P. R. (2016). Governing the smart city: A review of the literature on smart urban governance. International review of administrative sciences, 82(2), 392-408.

Muñoz-Erickson, T. A., Campbell, L. K., Childers, D. L., Grove, J. M., Iwaniec, D. M., Pickett, S. T. \& Svendsen, E. S. (2016). Demystifying governance and its role for transitions in urban social-ecological systems. Ecosphere, 7(11)
Nguyen, T. B. N., Do, T. L. (2020). Some solutions of "Smart city" in response to urban climate change. In IOP Conference Series: Materials Science and Engineering (Vol. 869, No. 2).

NIUA (National Institute of Urban Affairs). (2020). Climate Smart Cities Assessment Framework. https://csc.urbanindustrial.in/downloads/public_downloads/index_eng.html.

Odendaal, N. (2003). Information and communication technology and local governance: Understanding the difference between cities in developed and emerging economies. Computers, Environment and Urban Systems, 27(6), 585-607.

Okada, N. (2018). Adaptive process for SMART community governance under persistent disruptive risks. International Journal of Disaster Risk Science, 9(4), 454-463.

Parks, D. (2019). Energy efficiency left behind? Policy assemblages in Sweden's most climate-smart city. European Planning Studies, 27(2), 318-335.

Peker, E., Aydın, C.İ. (2019). Değişen İklim de Kentler: Yerel Yönetimler İçin Azaltım Ve Uyum Politikaları. İstanbul Politikalar Merkezi Bilgi Notu.

Praharaj, S., Han, J. H., Hawken, S. (2017). Urban innovation through policy integration: Critical perspectives from 100 smart cities mission in India. City, Culture and Society.

Pieterse, A., du Toit, J., Van Niekerk, W. (2020). Climate change adaptation mainstreaming in the planning instruments of two South African local municipalities. Development Southern Africa, 1-16.

Pereira, G. V., Parycek, P., Falco, E., Kleinhans, R. (2018). Smart governance in the context of smart cities: A literature review. Information Polity, 23(2), 143-162.

Shelton, T., Zook, M., Wiig, A. (2015). The "actually existing smart city".Journal of Regions, Economy and Society, 8(1), 13-25.

Smith, P. F. (2009). Building for a changing climate: The challenge for construction, planning and energy. Earthscan.

Soomro, K., Khan, Z., Ludlow, D. (2017). Participatory governance in smart cities: The urbanAPI case study. International Journal of Services Technology and Management, 23(5-6), 419-444.

Stone, P. J., Dunphy, D. C., Smith, M. S. (1966). The general inquirer: A computer approach to content analysis.

Şahin, Ü. (2014). Türkiyénin İklim Politikalarında Aktör Haritası. İstanbul Politikalar Merkezi. İstanbul.

Tanner, T., Mitchell, T., Polack, E., Guenther, B. (2009). Urban governance for adaptation: Assessing climate change resilience in ten Asian cities. IDS Working Papers, 2009(315), 1-47. 